
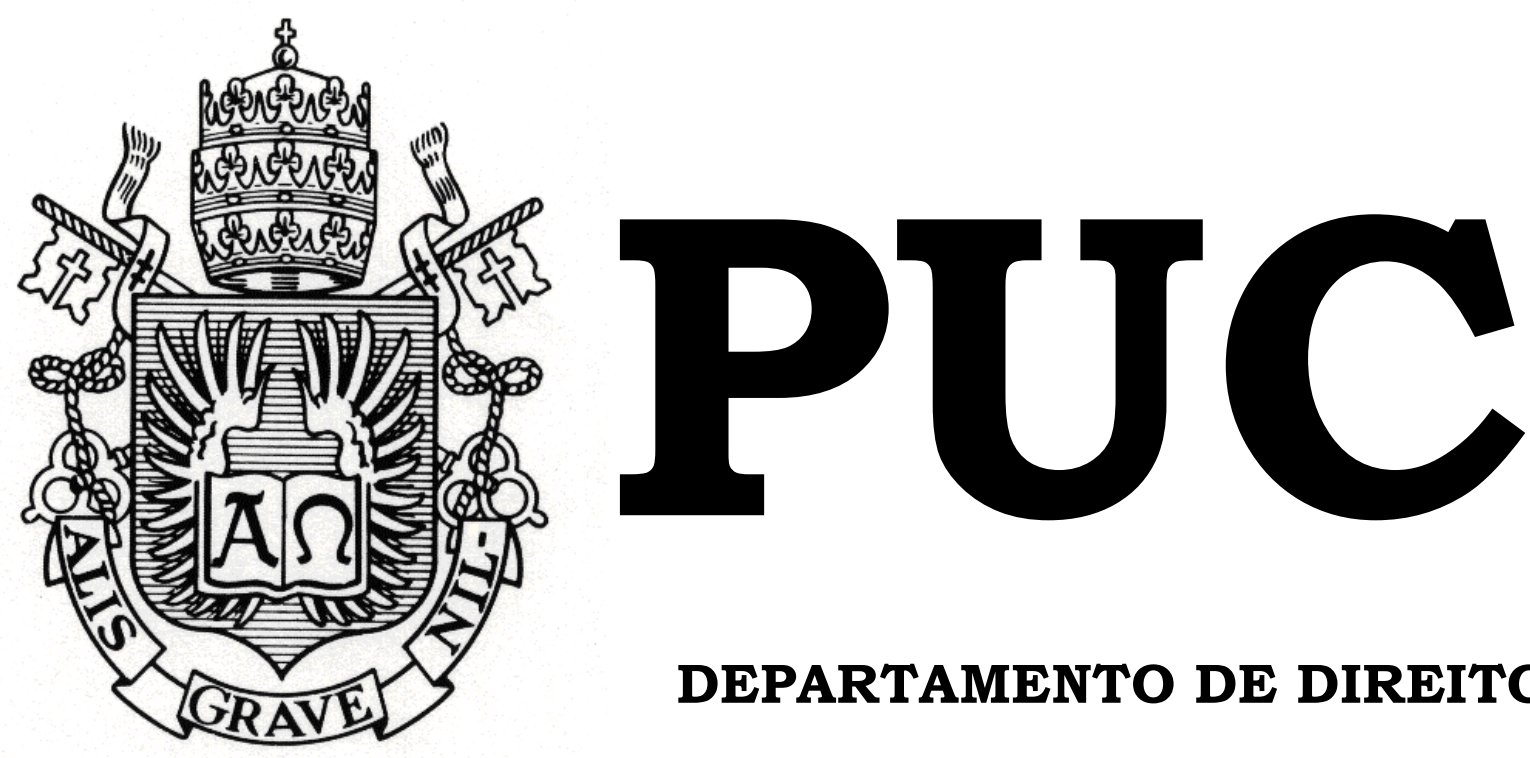

DEPARTAMENTO DE DIREITO

\title{
A DESCONSIDERAÇÃO DA PERSONALIDADE JURÍDICA NO NOVO CPC
}

\author{
Por \\ PEDRO FURTADO DE MENDONÇA BELLAS
}

ORIENTADOR: Leonardo Duncan Moreira Lima

2019.1

PONTIFÍCIA UNIVERSIDADE CATÓLICA DO RIO DE JANEIRO

RUA MARQUÊS DE SÃO VICENTE, 225 - CEP 22451-900

RIO DE JANEIRO - BRASIL 


\title{
A DESCONSIDERAÇÃO DA PERSONALIDADE JURÍDICA NO NOVO CPC \\ por
}

\section{PEDRO FURTADO DE MENDONÇA BELLAS}

\author{
Monografia apresentada ao \\ Departamento de Direito da \\ Pontificia Universidade Católica do \\ Rio de Janeiro (PUC-Rio) para a \\ obtenção do Título de Bacharel em \\ Direito.
}

Orientador: Leonardo Duncan Moreira Lima 


\section{Resumo e Palavras-Chave}

BELlAS, Pedro Furtado de Mendonça. A Desconsideração da Personalidade Jurídica no Novo CPC. Rio de Janeiro: 2019: 54 p. Monografia de final de curso. Departamento de Direito da Pontifícia Universidade Católica do Rio de Janeiro - PUC-Rio.

A presente monografia tem como objetivo a análise da desconsideração da personalidade jurídica, instituto de direito material, no âmbito do processo civil. De modo suscinto, primeiramente, é abordada a constituição de uma pessoa jurídica e o momento em que esta adquire sua personalidade para fins de Direito. Os trabalhos prosseguem com a explicação e a demonstração da aceitação da teoria da desconsideração da personalidade jurídica no âmbito do direito material. Por derradeiro, faz-se a análise do sistema processual para a desconsideração, sobretudo com o estudo do novo Incidente de Desconsideração da Personalidade Jurídica. Nesse passo, são demonstrados seus benefícios e algumas limitações de suas disposições, com o comparativo de como a questão era abordada anteriormente e como o novo CPC trouxe progresso para a matéria, acima especialmente em relação ao atendimento à ampla defesa e contraditório para os sócios.

Palavras-Chave: Pessoa Jurídica - Desconsideração da Personalidade Jurídica - Novo Código de Processo Civil - Intervenção de Terceiros - arts. 133 a 137 - Ampla defesa e contraditório. 


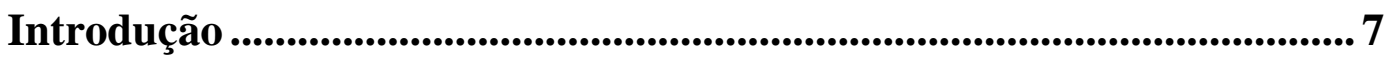

\section{Capítulo I - A Relevância da Constituição da Personalidade Jurídica Da}

Pessoa Jurídica.........................................................................................9

I.1 - A superação da discussão filosófica acerca da existência da personalidade jurídica para o Direito. ............................................... 9

I.2 - Quanto ao momento do surgimento da personalidade jurídica...... 10

I.3 - Dos efeitos da personalidade jurídica para as sociedades.............. 12

\section{Capítulo II - A Desconsideração da Personalidade Jurídica no Direito}

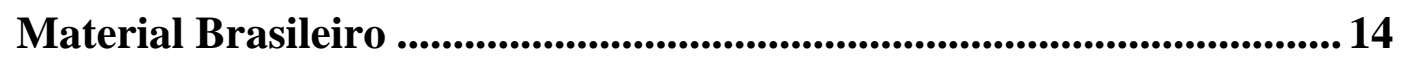

II.1 - Razões para a desconsideração e ressalvas quanto à limitação do ato. 14

II.2 - Breve Histórico da Ideia de Desconsideração. 17

II.3 - Aceitação da teoria da desconsideração pelo ordenamento jurídico

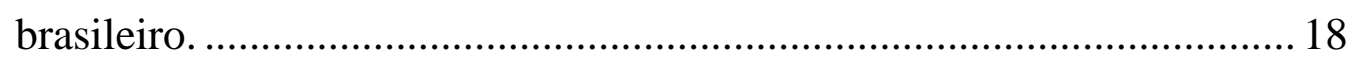

II.3.1 - Art. 50 do Código Civil - teoria maior da desconsideração da personalidade jurídica. ............................................................. 18

II.3.1.1 - Mudanças no art. 50 do Código Civil trazidas pela Medida Provisória $\mathrm{n}^{\circ} 881$, de 2019. 21

II.3.2 - Art. 28 do Código de Defesa do Consumidor - teoria menor da desconsideração da personalidade jurídica.................................... 24

II.3.3 - Outras disposições de Direito Material sobre a possibilidade de

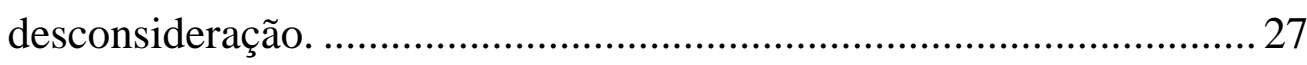

II.3.4 - Desconsideração inversa da personalidade jurídica............... 28 


\section{Capítulo III - Procedimento de Desconsideração da Personalidade}

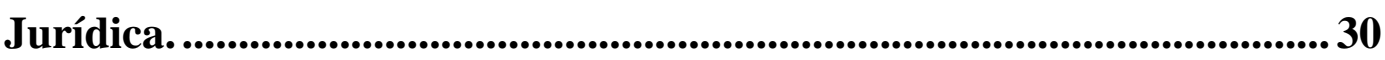

III.1 - Breve Panorama Pré-CPC/15 ................................................... 30

III.2 - Incidente de Desconsideração da Personalidade Jurídica: Análise Pormenorizada dos arts. 133 a 137 do CPC/15 ........................................ 33

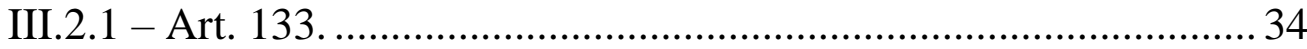

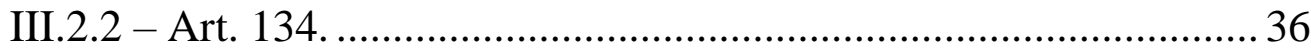

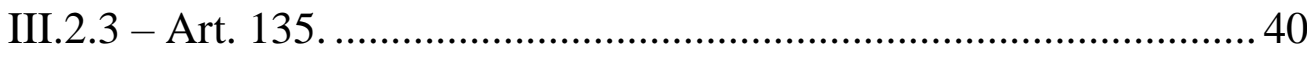

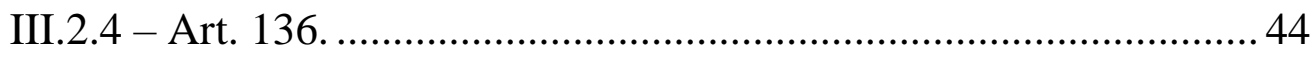

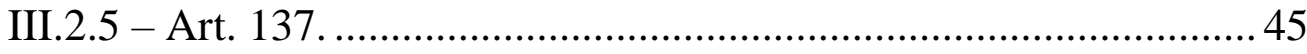

III.3 - Enaltecimento do Instituto do IDPJ: ampla cognição que prima pela atendimento às garantias constitucionais processuais para o demandado. 46

III.4 - Algumas Inconsistências do Instituto do Incidente de Desconsideração da Personalidade Jurídica. ............................................... 49

III.4.1 - Cabimento de honorários advocatícios nos casos de

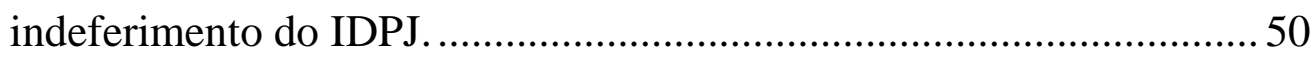

III.4.2 - Possibilidade de sustentação oral no Agravo de Instrumento interposto em face de decisão interlocutória que resolveu o IDPJ........54

III.4.2.1 - Em razão da complexidade do instituto: necessidade de atendimento a ampla defesa e contraditório......................................... 54

III.4.2.2 - Em razão do necessário tratamento isonômico com a desconsideração da personalidade jurídica decidida por sentença....56

Referências Bibliográficas .................................................................................... 61 


\section{Lista de AbreVIações e Símbolos}

Art. - Artigo;

CC - Código Civil de 2002 (Lei n 10.406/2002);

CC/16 - Código Civil de 1916 (Lei n³.071/1916);

CDC - Código de Defesa do Consumidor (Lei 8.078/1990);

Coords. - Coordenadores;

CPC/73 - Código de Processo Civil de 1973 (Lei 5.869/1973);

CPC/15 - Código de Processo Civil de 2015 (Lei 13.105/2015);

CRFB/88 - Constituição da República Federativa do Brasil de 1988;

Des. - Desembargador(a);

Ed. - Edição;

FPPC - Fórum Permanente dos Processualistas Civis;

Ibid. - Ibidem;

IDPJ - Incidente de Desconsideração da Personalidade Jurídica;

J. - Julgado;

Min. - Ministro(a);

MP - Medida Provisória;

Op. Cit. - Opus citatum;

P. - Página;

Rel. - Relator(a);

REsp - Recurso Especial;

Sic. - "exatamente assim";

STF - Supremo Tribunal Federal;

STJ - Superior Tribunal de Justiça; 
TJRJ - Tribunal de Justiça do Rio de Janeiro;

TJRS - Tribunal de Justiça do Rio Grande do Sul;

TJSP - Tribunal de Justiça de São Paulo;

V. - Volume;

§ - Parágrafo. 


\section{INTRODUÇÃO}

A emergência de um Novo Código de Processo Civil trouxe consigo relevantes mudanças nesse fundamental ramo do Direito. Uma delas foi incluir uma nova modalidade de Intervenção de Terceiros, o Incidente de Desconsideração da Personalidade Jurídica, instituto esmiuçado no presente trabalho.

A importância do tema reside na necessária segurança jurídica que deve se prover àqueles que fundam, administram e investem seu dinheiro nas mais diversas pessoas jurídicas existentes em nosso ordenamento pátrio. Configurando-se o capitalismo como pilar econômico que caracteriza a comunidade brasileira, o Direito não pode ficar inerte à proteção daqueles que contribuem para o seu desenvolvimento.

Nessa toada, o princípio da autonomia patrimonial entre os patrimônios dos sócios e das sociedades as quais eles fazem parte assume papel de nítido comprometimento com o desenvolvimento econômico social brasileiro. Ele fornece a segurança jurídica necessária para que o empreendedor invista em seu negócio sem comprometer seus rendimentos pessoais, o que ajuda a aumentar o nível econômico nacional.

Nada obstante, em caso de abuso da personalidade jurídica de sua sociedade, os sócios precisam responder com seu próprio patrimônio, uma vez que desvirtuam a finalidade de um instituto que existe para beneficia-los, mas que que foi utilizado de forma indevida. Nesse ponto, como o direito processual, em seu aspecto contencioso, pressupõe a existência de um atrito entre as partes com interesse na demanda, é fundamental que se analise judicialmente a ocorrência de tal prática antes da punição dos agentes que, supostamente, a realizaram.

É nesse tópico que se faz presente o novo Incidente de Desconsideração da Personalidade Jurídica, tendo em vista que a sua criação tem como escopo trazer o devido processo legal para o tema, em verdadeira 
inovação nesse ramo. Conforme será visto, antes do advento do CPC/15, poder-se-ia atingir o patrimônio dos sócios e incluí-los em uma demanda judicial sem que se defendessem de tal requerimento, em cristalina afronta aos princípios da ampla defesa e do contraditório, verdadeiros pilares do direito processual brasileiro. Objetivando a correção desse problema, o novo procedimento traz a ampla possibilidade de defesa para os sócios (ou, nos casos de desconsideração inversa, para a própria sociedade), de modo a valorizar o princípio da autonomia patrimonial, inclusive com referência ao duplo grau de jurisdição, ao prever modalidades recursais via Agravo de Instrumento ou Apelação, a depender do caso.

Desse modo, demonstrada a relevância da questão, digna de nota a metodologia empregada no presente trabalho, na qual se abordará primeiro o surgimento da pessoa jurídica, separando-a da pessoa física que a constituiu. A seguir, passa-se a expor o instituto da própria desconsideração da personalidade jurídica e sua aceitação pelo ordenamento jurídico brasileiro sob a ótica do direito material. Por fim, os trabalhos serão focados no procedimento da desconsideração no âmbito do novo códex processual civil, etapa na qual o instituto será avaliado de modo crítico, tanto em seus aspectos positivos, sobretudo ampla defesa e contraditório, como em algumas consistências. 


\section{Capítulo I - A Relevância da Constituição da Personalidade JuRídica da Pessoa JURÍdica.}

A pessoa jurídica é um dos elementos mais significativos do Direito. Ela se configura como a representação, no mundo jurídico, da força da união entre pessoas físicas que visam um objetivo, que é mais facilmente alcançado quando se provê relevância fática a essa junção. Da criação dessa pessoa jurídica, para fins jurídicos, advém o surgimento da personalidade jurídica, da qual a pessoa jurídica fará uso para que exerça sua vontade e autonomia independentes, do ponto de vista jurídico, daquelas pessoas que a criaram.

\section{I.1 - A SUPERAÇÃo DA DISCUSSÃo FILOSÓFICA ACERCA DA EXISTÊNCIA DA PERSONALIDADE JURÍDICA PARA O DIREITO.}

Antes, contudo, de adentrar nos meandros do Direito para a referida questão, relevante destacar a abordagem filosófica de YUVAL NOAH HARARI $^{1}$, que compara a criação de sociedades jurídicas a antigos rituais de feitiçaria ancestrais, de modo a deixar claro que aquilo conhecido comumente como empresas nada mais são do que invenções criadas pelo ser humano para facilitar as suas relações econômicas.

Esse aspecto é relevantíssimo para o escopo da criação de sociedades que visam ao lucro, uma vez que a separação das esferas jurídicas de sócios e sociedade empresária fomenta a própria atividade empresarial e a facilita, encorajando pessoas a abrirem negócios. Isto porque a eventual falência de uma sociedade empresária não implicará, a princípio, na derradeira insolvência das pessoas físicas que a criaram ${ }^{2}$, dada a independência entre os patrimônios dos dois referidos sujeitos de Direito.

\footnotetext{
${ }^{1}$ HARARI, Yuval Noah. Sapiens - Uma breve história da humanidade. Tradução Janaína Marcoantonio - Porto Alegre, RS: L\&PM POCKET, 2018. p. 51-52.

${ }^{2}$ Ibid. p. 50.
} 
Cumpre ressaltar que o fato de uma sociedade se configurar como uma “ilusão" e a sua personalidade ser uma mera ficção jurídica ${ }^{3}$, não implica em diminuir em nada a relevância que essas pessoas jurídicas possuem. Nesse sentido, conforme defende RUBENS REQUIÃO ${ }^{4}$, a abordagem da questão da existência da pessoa jurídica deve ser levada em consideração do ponto de vista eminentemente prático, destacando que, mesmo que tenhamos discussões filosóficas acerca da existência ou não das sociedades, o importante é que elas estão contidas dentro do mundo jurídico e existem para este.

Sobre esse entendimento, ORLANDO GOMES afirma:

“(...) Dúvida não pode haver de que o agrupamento de seres humanos para a realização do fim comum, reunindo esforços e capitais, é imperativo da própria organização social, como é o contrato para a disciplina de certos interesses. Conseqüentemente, esse fato que a sociedade gera, não é uma abstração, mas, sim, evidente realidade. O Direito apercebe-se de sua existência, e, por processo técnico, possibilita a atividade social dos que se agrupam para exercê-la. Esse processo técnico é a personificação. Consiste, precisamente, em atribuir personalidade ao grupo, para que possa exercer a atividade jurídica como uma unidade, tal como se fosse uma pessoa natural. A explicação é aceitável, resultando, como resulta, da observação da realidade social. (...)" ${ }^{n}$

Portanto, corroborando a relevância da existência da personalidade para as pessoas jurídicas, percebe-se que resta pouco prática a discussão filosófica acerca da personalização e até mesmo da própria existência da pessoa jurídica.

\section{I.2 - QUANTO AO MOMENTO DO SURGIMENTO DA PERSONALIDADE JURÍDICA.}

Tendo em vista a existência de acordo de vontades entre pessoas físicas para a constituição de uma sociedade empresária, está formado o

\footnotetext{
${ }^{3}$ NEGRÃO, Ricardo. Manual de direito comercial e de empresa, volume 1. 9. ed. São Paulo: Saraiva, 2012. p. 267.

${ }^{4}$ REQUIÃO, Rubens. Curso de direito comercial: volume 1. 33. ed., rev. e atual por Rubens Edmundo Requião. São Paulo: Saraiva, 2014. p. 471.

${ }^{5}$ GOMES, Orlando, 1909-1988. Introdução do direito civil. Revista, atualizada e aumentada, de acordo com o Código Civil de 2002, por Edvaldo Brito e Reginalda Paranhos de Brito. - Rio de Janeiro: Forense, 2008. p. 170.
} 
embrião que constituirá a pessoa jurídica e, consequentemente, sua personalidade jurídica. Portanto, o desejo de união para a formação de uma sociedade empresária visando o lucro, na qual há entre os sócios "uma vontade de cooperar, assumindo os figurantes a responsabilidade dos resultados da atividade social"6, o que usualmente é conhecido como affectio societatis, é o primeiro passo para a o soerguimento da personalidade jurídica da sociedade.

Nessa toada, defende RUBENS REQUIÃO:

"quando a comunhão é dotada de movimento próprio, de atividade sua, de vontade real, quando em suma, é animada pelo desígnio de obter um lucro ou vantagem econômica, eis que surge a personalidade"7

Nada obstante a relevância do requisito "vontade" na configuração da pessoa jurídica, não se pode perder de vista que esta tem o seu surgimento atrelado a estrita previsão legal. Nesse passo, a pessoa jurídica nasce para o direito privado, conforme os ditames do art. 45 do $\mathrm{CC}^{8}$, em razão da inscrição de seus atos constitutivos no respectivo registro competente. $\mathrm{O}$ arquivamento deles, segundo FRAN MARTINS, é a "condição essencial para que a pessoa jurídica tenha existência legal"'. Outrossim, ainda nesse momento, consoante RUBENS REQUIÃO ${ }^{10}$, a pessoa jurídica adquire a sua personalidade jurídica.

Relevante destacar que, na esteira do $\mathrm{CC} / 16$, havia entendimento doutrinário no sentido de se entender que a personalidade jurídica das denominadas, à época, "sociedades mercantis", poderia surgir antes do registro, tendo em vista o disposto no art. $16, \S 2^{\circ}$, da Parte Geral do revogado

\footnotetext{
${ }^{6}$ RIZZARDO, Arnaldo. Parte Geral do Código Civil: Lei n ${ }^{\circ}$ 10.406, de 10.01.2002. $4^{a}$ ed. Rio de Janeiro: Forense, 2006. p. 250.

${ }^{7}$ REQUIÃO, Rubens. 2014. p. 472.

${ }^{8}$ Código Civil de 2002, art. 45: "Começa a existência legal das pessoas jurídicas de direito privado com a inscrição do ato constitutivo no respectivo registro, precedida, quando necessário, de autorização ou aprovação do Poder Executivo, averbando-se no registro todas as alterações por que passar o ato constitutivo."

9 MARTINS, Fran. Curso de direito comercial: empresa comercial, empresários individuais, microempresas, sociedades comerciais, fundo de comércio. Ed. rev. e atual. Rio de Janeiro: Forense, 2008. p. 188.

${ }^{10}$ REQUIÃO, Rubens. 2014. p. 480.
} 
Códex civil ${ }^{11}$. Entretanto, o advento do art. 45 do atual Código Civil pôs fim a essa divergência, delimitando, sem dúvidas, o momento do surgimento da personalidade jurídica como sendo o registro, uma vez que essa regra é aplicada a todas as pessoas jurídicas de direito privado. ${ }^{12}$

\section{I.3 - DOS EFEITOS DA PERSONALIDADE JURÍDICA PARA AS SOCIEDADES.}

A partir do momento em que se faz constituída a personalidade jurídica, a sociedade que possui a sua titularidade passa a emanar uma série de efeitos.

O primeiro deles, conforme RICARDO NEGRÃO ${ }^{13}$, é a titularidade da sociedade para gerir negócio e possuir representação processual própria. Isto significa dizer que a própria sociedade será sujeito de direito para poder contratar e figurar em ambos os polos de um processo. Essa questão está diretamente ligada à questão da individualização entre sócio e sociedade, que não mais têm as suas pessoas confundidas a partir do surgimento da personalidade jurídica.

Por derradeiro, somam-se a esses efeitos alguns outros secundários, que não trarão implicações significativas. Dentre eles, pode-se destacar o fato de a pessoa jurídica possuir os direitos inerentes à personalidade (art. 52, do $\mathrm{CC}^{14}$ ), algo diretamente relacionado ao papel desempenhado pela pessoa jurídica em nossa comunidade, no tocante não só às suas características patrimoniais, mas também no aspecto de reafirmação de valores sociais. ${ }^{15}$

\footnotetext{
${ }^{11}$ Código Civil de 1916, Parte Geral, art. 16: "São pessoas jurídicas de direito privado: (...) $\S 2^{\circ} \mathrm{As}$ sociedades mercantis continuarão a reger-se pelo estatuto nas leis comerciais."

${ }^{12}$ GIORDANI, José Acir Lessa. Curso Básico de Direito Civil: parte geral. $4^{a}$ edição, revista e atualizada pelo Novo Código Civil - Rio de Janeiro: Lumen Juris, 2006. p. 128.

${ }^{13}$ NEGRÃO, Ricardo. 2012. p. 268-269.

${ }^{14}$ Código Civil de 2002, art. 52: "Aplica-se às pessoas jurídicas, no que couber, a proteção dos direitos da personalidade."

${ }^{15}$ TEPEDINO, Gustavo. Temas de direito civil. $4^{\mathrm{a}}$ edição revista e atualizada. - Rio de Janeiro: Renovar, 2008. p. 580.
} 
Como exemplo desses direitos, pontua-se o direito fundamental ao nome, esculpido no art. $5^{\circ}$, XXIX, da CRFB $/ 88^{16}$, o direito de possuir domicílio próprio ${ }^{17}$ e reparação em virtude de danos morais sofridos (Súmula $\left.227 / \mathrm{STJ}^{18}\right)$.

Por derradeiro, um aspecto que guarda extrema relevância é a reponsabilidade patrimonial da pessoa jurídica. Ainda nas palavras de RICARDO NEGRÃO:

\begin{abstract}
"Responsabilidade patrimonial: a pessoa jurídica possui patrimônio próprio, distinto de seus sócios. É este patrimônio que se sujeita primariamente a responder pelas dívidas assumidas pela pessoa jurídica. Em algumas sociedades, o contrato prevê a responsabilidade dos sócios por saldos eventualmente existentes, mas esta será sempre de natureza subsidiária ou secundária, não se permitindo a execução de bens pessoais dos sócios antes dos bens da sociedade." 19
\end{abstract}

A separação entre os patrimônios do sócio e da sociedade da qual ele faz parte se constitui como uma das características mais essenciais para o escopo da desconsideração da personalidade jurídica que será abordada no presente trabalho, tendo em vista que a responsabilização patrimonial por determinados atos pode ser decisiva para que a aludida divisão de patrimônios seja afastada em um caso concreto.

Portanto, salienta-se que o instituto da desconsideração da personalidade jurídica visa a resguardar os interesses de credores contra devedores que, maliciosamente, usam das prerrogativas legais do instituto da pessoa jurídica e de sua personalidade para afagar seus próprios interesses e atingir objetivos particulares. Essa questão será melhor delineada no próximo capítulo.

\footnotetext{
${ }^{16}$ Constituição da República Federativa do Brasil de 1988, art. 5º "XXIX - a lei assegurará aos autores de inventos industriais privilégio temporário para sua utilização, bem como proteção às criações industriais, à propriedade das marcas, aos nomes de empresas e a outros signos distintivos, tendo em vista o interesse social e o desenvolvimento tecnológico e econômico do País;"

${ }^{17}$ MARTINS, Fran. 2008. p. 194.

${ }^{18}$ Enunciado ${ }^{\circ} 227$ da Súmula do STJ: "A pessoa jurídica pode sofrer dano moral."

${ }^{19}$ NEGRÃO, Ricardo. 2012. p. 269.
} 


\section{Capítulo II - A Desconsideração da Personalidade Jurídica no Direito Material Brasileiro.}

Conforme já abordado linhas acima, a desconsideração da personalidade jurídica, também conhecida como "disregard of legal entity" ou ainda "disregard doctrine", ocorre quando os sócios de uma sociedade utilizam das prerrogativas conferidas pelo legislador para a pessoa jurídica de modo abusivo, desvirtuando o escopo coletivo que deve permear as ações da sociedade. Nesse sentido, aqueles que deveriam zelar pelo atendimento dos objetivos coletivos da sociedade acabam utilizando-a para fins ilícitos, agindo em abuso de direito incompatível com a finalidade ou com a independência patrimonial da sociedade.

\section{II.1 - RAZÕES PARA A DESCONSIDERAÇÃo E RESSALVAS QUANTO À LIMITAÇÃo DO ATO.}

Segundo ARNALDO RIZZARDO ${ }^{20}$, a desconsideração da personalidade jurídica vai ocorrer "caso utilizada a pessoa jurídica para o proveito ilícito de seus sócios, desfalcando-se seu patrimônio de modo a não se capacitar a arcar com os compromissos assumidos".

Já para CAIO MARIO DA SILVA PEREIRA ${ }^{21}$, o aludido instituto visa a levantar o véu da personalidade jurídica, atribuindo responsabilidade aos sócios, de modo a "alcançar aquele, em fraude à lei ou ao contrato, ou por abuso de direito, procurou eximir-se por trás da personalidade jurídica e escapar, fazendo dela uma simples fachada para ocultar uma situação danosa".

Portanto, não se pode perder de vista que, por mais que a regra seja a separação de patrimônios e de responsabilidade entre sócios e a sociedade a

\footnotetext{
${ }^{20}$ RIZZARDO, Arnaldo. 2006. p. 253.

${ }^{21}$ PEREIRA, Caio Mario da Silva. Instituições de direito civil, V. 1, Introdução ao direito civil: teoria geral de direito civil. 26. ed. Rio de Janeiro: Forense, 2013. p. 281.
} 
qual eles integram, o uso indevido das características desta leva ao iminente afastamento de sua personalidade. De modo a ilustrar a repreensão a essa conduta, FRAN MARTINS chega a qualificar, de modo rígido, referidos sócios como "indivíduos desonestos" ou, ainda, "pessoas inescrupulosas"22. Essa suposta torpeza pode ser observada em três brilhantes exemplos trazidos por FABIO ULHOA COELHO ${ }^{23}$.

No primeiro deles, podemos observar um sócio proprietário de um estabelecimento de atividade industrial, que funda, juntamente com seu irmão, uma sociedade limitada na qual possui pequena participação. A desonestidade de tal pessoa é observada no momento em que, ao invés de integralizar o capital da nova sociedade com patrimônio da anterior, ele o vende para a limitada nascente. Assim, age de modo errôneo com os fins da sociedade, uma vez que passa a possuir direitos de credor e de sócio, e não apenas os relativos a este.

A segunda situação envolve processos judiciais. Trata-se de uma hipótese na qual uma sociedade anônima é condenada a ressarcir um consumidor por dano sofrido por este. Ao se ver nessa situação, o sócio da aludida S/A funda uma nova sociedade, dessa vez de responsabilidade limitada, completamente independente da primeira, e passa a investir apenas nesta, abandonando a sociedade original e devedora da ação em tela. Com a desistência em levar os negócios da sociedade anônima adiante, esta fica gradualmente sem patrimônio e não consegue honrar com seu débito judicial, enquanto o sócio nada sofre economicamente, eis que supostamente resguardado pela independência entre seu patrimônio e o da sociedade anônima devedora.

Finalmente, o terceiro exemplo envolve situação de truste. Nesse caso, cogita-se a existência de quatro sociedades do mesmo ramo, todas

\footnotetext{
${ }^{22}$ MARTINS, Fran. 2008. p. 195-196.

${ }^{23}$ COELHO, Fabio Ulhoa. Curso de direito comercial, volume 2: direito de empresa. - 15. ed. São Paulo: Saraiva, 2011. p. 52-55.
} 
independentes entre si. $\mathrm{O}$ administrador da mais robusta delas acorda com os controladores das outras sociedades que ele irá escolher os administradores delas, em troca da garantia de rentabilidade mínima. Nesse caso, percebe-se que, por mais que sejam quatro sociedades a princípio independentes, em última instância, eles possuem o mesmo controlador. Oportuno ressaltar que o art. 34 da Lei 12.529/201124, conhecida como Lei de Defesa da Concorrência, possui previsão expressa de desconsideração da personalidade jurídica em casos semelhantes a estes.

Nada obstante o reiterado mau uso observado das características de uma pessoa jurídica, a princípio criadas para beneficiar a atividade empreendedora, mas utilizadas eventualmente de forma abusiva, a desconsideração da personalidade jurídica aqui observada se revela apenas temporária e casuística.

Isto porque o afastamento da personalidade jurídica não implica na anulação desta relativamente à pessoa jurídica. Ou seja, o que se está fazendo na aplicação do instituto é apenas desconsiderar a personalidade jurídica para aquelas ações em que ficar caracterizado a extrapolação dos objetivos da pessoa jurídica, nos termos da lei. Nas precisas palavras de RUBENS REQUIÃO ${ }^{25}$, a desconsideração da personalidade jurídica " $n$ ão se trata, é bom esclarecer, de considerar ou declarar nula a personificação, mas de tornála ineficaz para determinados atos".

Nessa esteira, PAUlo LôBO ${ }^{26}$ compreende que "o ato desviante é válido, porém ineficaz. A ineficácia não desce ao plano da validade ou da existência. Não há falar, pois, em despersonalização".

\footnotetext{
${ }^{24}$ Lei 12.529/11, art. 34: "A personalidade jurídica do responsável por infração da ordem econômica poderá ser desconsiderada quando houver da parte deste abuso de direito, excesso de poder, infração da lei, fato ou ato ilícito ou violação dos estatutos ou contrato social. "

${ }^{25}$ REQUIÃO, Rubens. 2014. p. 476.

${ }^{26}$ LÔBO, Paulo. Direito Civil : parte geral. 3. ed. - São Paulo: Saraiva, 2012.
} 
Por fim, CAIO MARIO DA SILVA PEREIRA arremata a questão da limitação do alcance da desconsideração:

"Cumpre observar, todavia, que não se trata de decretar a nulidade ou a desconstituição da personalidade jurídica, senão, em dadas circunstâncias, proclamar-lhe a ineficácia, continuando a personalidade jurídica a subsistir para todo e qualquer ato." 27

\section{II.2 - BreVe Histórico da IDEIA DE Desconsideração.}

Examinada a definição e alcance da "disregard doctrine", passa-se, a título de riqueza do assunto, ao histórico de aplicação do instituto.

Nos primórdios da concepção de sua ideia, encontra-se um julgamento ocorrido na Inglaterra no final do século XIX. Trata-se do famoso caso Salomon vs. Salomon \& $\mathrm{Co}^{28}{ }^{29}$. Nele, um empresário chamado Aaron Salomon, proprietário de um fundo de comércio, fundou uma nova sociedade com a cessão desse empreendimento. Na nova configuração societária, Aaron Salomon era proprietário da quase totalidade das ações, sendo seis de seus familiares titulares de uma única cota delas. A nova sociedade, em pouco tempo, se revelou insolvente. Diante dessa situação, os credores quirografários argumentaram que Aaron Salomon tinha usado de sua nova sociedade para limitar sua responsabilidade, devendo responder pelas dívidas desta, uma vez que as atividades da pessoa física e da pessoa jurídica se confundiriam. A $1^{\mathrm{a}}$ instância e a Corte inglesas acolheram essa pretensão, reconhecendo que o fundo de comércio era de fato exercido pela pessoa de Aaron Salomon, desconsiderando, portanto, a personalidade jurídica da Salomon \& Co. Nada obstante, a decisão final da Casa dos Lordes em sentido contrário às outras instâncias minou a concretização fática da desconsideração nesse caso. Entretanto, essa demanda foi eternizada como o marco inicial da aplicação do instituto.

\footnotetext{
${ }^{27}$ PEREIRA, Caio Mario da Silva. 2013. p. 281.

${ }^{28}$ REQUIÃO Rubens. 2014. p. 476-477.

${ }^{29}$ COELHO, Fabio Ulhoa. 2011. p. 60.
} 
Posteriormente, em análise da jurisprudência americana ${ }^{30}$, Rolf Serick elaborou complexa sistemática em torno desse assunto, sendo esse jurista alemão considerado o seu principal expoente, ainda que não tenha sido o primeiro a fazer isso em sede doutrinária ${ }^{31}$.

\section{II.3 - ACEITAÇÃo DA TEORIA DA DESCONSIDERAÇÃo PELO ORDENAMENTO JURÍDICO BRASILEIRO.}

A teoria da "disregard of legal entity" é relativamente nova no ordenamento jurídico brasileiro. No que pese a sua positivação em nosso Direito, FABIo UlhoA COELHO defende que “deixar de aplica-la, a pretexto da inexistência de dispositivo legal expresso, significaria o mesmo que amparar a fraude" 32 . A despeito desse entendimento, que minimiza a existência de dispositivo legal autorizador da aplicação da desconsideração, se faz importante ressaltar que a presença do instituto em lei não só corrobora sua importância como facilita sua respectiva aplicação pelos operadores do Direito.

\section{II.3.1 - ART. 50 do Código CIVIL - TEORIA MAIOR DA DESCONSIDERAÇÃO DA PERSONALIDADE JURÍDICA.}

A positivação mais notória do instituto da desconsideração da personalidade jurídica no Direito Material é aquela presente no art. 50 do CC, sendo ele assim redigido:

"Art. 50. Em caso de abuso da personalidade jurídica, caracterizado pelo desvio de finalidade, ou pela confusão patrimonial, pode o juiz decidir, a requerimento da parte, ou do Ministério Público quando lhe couber intervir no processo, que os

\footnotetext{
${ }^{30}$ PEREIRA, Caio Maio da Silva. 2013. p. 282.

${ }^{31}$ COELHO, Fabio Ulhoa. 2011, p. 56.

${ }^{32}$ Ibid. p. 57.
} 
efeitos de certas e determinadas relações de obrigações sejam estendidos aos bens particulares dos administradores ou sócios da pessoa jurídica." ${ }^{33}$

Da mera leitura do aludido comando legal, resta claro que deve haver abuso na condução da personalidade jurídica para que possa haver a sua desconsideração em casos pontuais, respondendo o patrimônio dos sócios por dívidas da sociedade. O texto legal traz, ainda, dois requisitos para ocorrência do afastamento oportuno da personalidade, quais sejam, "desvio de finalidade" e "confusão patrimonial". Nesse passo, mostra-se possível a classificação do primeiro como um critério subjetivo para desconsideração, eis que dependente de um animus dos sócios em realizar o ato ilícito, e o segundo, como um requisito objetivo para a ocorrência do fenômeno, uma vez que este poderá ser mais facilmente comprovado, exigindo-se apenas documentos que atestem o uso indevido do patrimônio da sociedade pelos sócios. $^{34}$

Nessa toada, segundo ARNALDO RIZZARDO, “[o] desvio de finalidade consiste no direcionamento da sociedade para atividades ou objeto diferentes daqueles que constas [sic] dos estatutos ou do contrato social". ${ }^{35}$ Por sua vez, para o mesmo autor, "[a] confusão patrimonial se dá na transferência do patrimônio social para o nome dos administradores ou sócios"36.

A redação civilista, consoante lição de PAULO LÔBO $^{37}$, se propõe a traçar limites objetivos para a desconsideração, uma vez que o abuso da personalidade, decorrente de desvio de finalidade ou confusão patrimonial, prescinde do elemento volitivo, bastando apenas a existência do fato danoso,

\footnotetext{
${ }^{33}$ A redação apresentada é aquela vigente antes da edição da Medida Provisória nº 881, de 2019, cujas mudanças serão abordadas no Capítulo II.3.1.1.

${ }^{34}$ COELHO, Fabio Ulhoa. Op. Cit. p. 63-64.

${ }^{35}$ RIZZARDO, Arnaldo. 2006. p. 296.

${ }^{36}$ Ibid. p. 296.

${ }^{37}$ LÔBO, Paulo. 2012. p. 174.
} 
sem que haja necessariamente intenção de causar acintosamente o desvirtuamento da pessoa jurídica. ${ }^{38}$

Nada obstante, em relação ao texto legal do art. 50 do CC, GUSTAVO Tepedino, Heloisa Helena Barboza e Maria Celina Bodin de Moraes tecem severas críticas, afirmando que o detalhamento do dispositivo cível contribui para uma menor aplicação do instituto da desconsideração. Para esses doutrinadores, seria mais interessante que o texto fosse simples como seu correspondente no $\mathrm{CDC}^{39}$. Para essa questão levantada, os nobres doutrinadores trazem a seguinte solução:

“(...) Mencionando diretamente a possibilidade de o juiz 'desconsiderar a personalidade jurídica', não municia aqueles que buscam apenas encontrar no texto legal brechas que permitam uma escapatória ao adimplemento de suas obrigações, como faz o art. 50 do CC, em nítido retrocesso (...)"40 41

Entretanto, relevante destacar que a construção do texto do art. 50 do $\mathrm{CC}$, independente do verbo utilizado no texto legal para caracterizar a atitude do juiz diante da desconsideração da personalidade jurídica, possui um teor que tem como base uma grande gama de requisitos para a desconsideração. Consequentemente, isto contribui para o melhor atendimento ao escopo do instituto, uma vez que este deve ter aplicação excepcional e episódica ${ }^{42}$, não podendo a desconsideração ser utilizada em todos os casos de inadimplemento da sociedade. Nesse passo, reforça-se o princípio da autonomia patrimonial entre sócios e a pessoa jurídica da qual eles fazem parte, sendo que a ruptura dessa segregação deve ser de caráter extraordinário, não se podendo banalizar o instituto.

\footnotetext{
${ }^{38}$ Essa questão, conforme será visto no Capítulo II.3.1.1, não mais subsiste após a edição da Medida Provisória 881, de 2019, em razão da exigência da prova da conduta dolosa por parte do sócio, no caso específico de "desvio de finalidade", consoante comando do novel art. 50, § $1^{\circ}, \mathrm{CC}$.

${ }^{39}$ As disposições do CDC acerca do tema serão vistas mais detalhadamente no Capítulo III.3.2.

${ }^{40}$ TEPEDINO, Gustavo; BARBOZA, Heloisa Helena; MORAES, Maria Celina Bodin. Código Civil interpretado: Conforme a Constituição da República. Rio de Janeiro: Renovar, 2004. p. 128.

${ }^{41}$ A nova redação do art. 50, caput, do CC, conferida pela Medida Provisória $n^{\circ} 881$, de 2019, atendeu ao anseio aqui demonstrado, ao incluir o verbo "desconsiderar" em suas disposições.

${ }^{42}$ LÔBO, Paulo. 2012. p. 175.
} 


\title{
II.3.1.1 - Mudanças No ART. 50 do Código Civil trazidas Pela Medida ProvisóRIA N 881, DE 2019.
}

Editada em 30 de abril de 2019, a Medida Provisória ${ }^{\circ} 881$ trouxe modificações ao art. 50 do $\mathrm{CC}$, alterando o disposto em seu caput e adicionando cinco parágrafos ao texto legal, trazendo transformações significativas ao regramento da desconsideração da personalidade jurídica, conforme se observa a seguir:

\begin{abstract}
“Art. 50. Em caso de abuso da personalidade jurídica, caracterizado pelo desvio de finalidade ou pela confusão patrimonial, pode o juiz, a requerimento da parte, ou do Ministério Público quando lhe couber intervir no processo, desconsiderá-la para que os efeitos de certas e determinadas relações de obrigações sejam estendidos aos bens particulares de administradores ou de sócios da pessoa jurídica beneficiados direta ou indiretamente pelo abuso.
\end{abstract}

$\S 1^{\circ}$ Para fins do disposto neste artigo, desvio de finalidade é a utilização dolosa da pessoa jurídica com o propósito de lesar credores e para a prática de atos ilícitos de qualquer natureza.

$\S 2^{\circ}$ Entende-se por confusão patrimonial a ausência de separação de fato entre os patrimônios, caracterizada por:

I - cumprimento repetitivo pela sociedade de obrigações do sócio ou do administrador ou vice-versa;

II - transferência de ativos ou de passivos sem efetivas contraprestações, exceto o de valor proporcionalmente insignificante; $\mathrm{e}$

III - outros atos de descumprimento da autonomia patrimonial.

$\S 3^{\circ} \mathrm{O}$ disposto no caput e nos $\S 1^{\circ}$ e $\S 2^{\circ}$ também se aplica à extensão das obrigações de sócios ou de administradores à pessoa jurídica.

$\S 4^{\circ}$ A mera existência de grupo econômico sem a presença dos requisitos de que trata o caput não autoriza a desconsideração da personalidade da pessoa jurídica.

$\S 5^{\circ}$ Não constitui desvio de finalidade a mera expansão ou a alteração da finalidade original da atividade econômica específica da pessoa jurídica."

Da observação primária do novo ditame legal, destaca-se que o caput foi alterado de modo a focar a incursão no patrimônio daqueles que realmente foram beneficiados com o abuso da personalidade da pessoa jurídica ${ }^{43}$,

${ }^{43}$ GRANER, Fabio; OLIVON, Beatriz. Governo inclui jurisprudência do STJ sobre confusão patrimonial em MP. Valor Econômico. São Paulo, p. E1, 17 mai. 2019. 
consoante a observação da parte final do dispositivo. Esse aspecto é realçado por FLÁVIO TARTUCE:

"Como primeira alteração destacada, nota-se que a lei passaria a possibilitar a desconsideração da personalidade jurídica tão somente quanto ao sócio ou administrador que, direta ou indiretamente, for beneficiado pelo abuso, o que há tempos defendo, para que o instituto não seja utilizado de forma desproporcional e desmedida, atingindo pessoa natural que não tenha praticado o ato tido como abusivo." 44

De igual notabilidade, percebe-se que os critérios de "desvio de personalidade" e "confusão patrimonial", enquanto determinantes para a caracterização do abuso da personalidade jurídica, foram mantidos na lei. Entretanto, diferentemente do que era disposto até então, agora há a positivação dos pressupostos necessários para que ambos sejam atendidos, tarefa que antes coube à doutrina e jurisprudência ${ }^{45}$.

No que diz respeito ao "desvio de personalidade", há o estabelecimento, no $\S 1^{\circ}$, de um critério de extrema turbulência, qual seja, a necessidade de dolo do sócio (ou da sociedade, nos casos de desconsideração inversa) no cometimento do ato abusivo da personalidade da sociedade. Isto, por si só, seguramente deixará os casos de desconsideração da personalidade jurídica mais escassos, tendo em vista que a intenção subjetiva no cometimento do abuso, por parte do sócio, deverá ser comprovada por quem requer a desconsideração.

A seu turno, a "confusão patrimonial" não sofreu grandes abalos, sendo que os critérios estabelecidos, sobretudo o disposto no $\S 2^{\circ}$, III, apenas confirmam a necessidade sublime de separação patrimonial entre sócios e

\footnotetext{
${ }^{44}$ TARTUCE, Flávio. A Medida Provisória 881/2019 e as Alterações do Código Civil - Primeira Parte: Desconsideração da personalidade jurídica e função social do contrato. Disponível em <https://flaviotartuce.jusbrasil.com.br/artigos/703994479/a-medida-provisoria-881-2019-e-asalteracoes-do-codigo-civil-primeira-parte-desconsideracao-da-personalidade-juridica-e-funcaosocial-do-contrato>. Acesso em 13 mai. 2019.

${ }^{45}$ TOMASEVICIUS FILHO, Eduardo. MP da "liberdade econômica": o que fizeram com o Direito Civil?. Disponível em <https://www.conjur.com.br/2019-mai-13/direito-civil-atual-mp-liberdadeeconomica-fizeram-direito-civil>. Acesso em 13 mai. 2019.
} 
sociedade, reforçando a autonomia patrimonial como um pilar da personalidade jurídica de uma pessoa jurídica.

Por sua vez, o $\S 3^{\circ}$ traz a positivação, no direito material, da desconsideração inversa da personalidade jurídica. Essa situação, conforme será melhor abordado no Capítulo II.3.4, ocorre quando o sócio possui dívidas pessoais, as quais ele não honra, utilizando a pessoa jurídica a qual ele integra como uma facilitadora dessa ocultação. Nesses casos, o patrimônio da pessoa jurídica pode responder pelas dívidas pessoais dos sócios, confirmando um entendimento já vastamente aceito pela doutrina e que também se faz presente expressamente no art. $133, \S 2^{\circ}, \mathrm{CPC} / 15^{46}$.

Ademais, a proibição da pressuposição do abuso da personalidade jurídica se encontra reforçada no $\S 4^{\circ}$, o qual versa sobre situações em que a mera existência de grupos econômicos não configura, por si só, a desconsideração das personalidades jurídicas das sociedades pertencentes a eles, situação que visaria atingir o patrimônio de sua controladora. Nesse passo, a lei reafirma que, em casos como esses - tal como em quaisquer outras situações -, deve-se comprovar os requisitos autorizadores da "disregard doctrine".

Por fim, o $\S 5^{\circ}$ trata de uma situação específica apta a afastar um possível desvio de finalidade da sociedade. Ao utilizar a palavra "mera" para definir a questão da expansão de atividades econômica, assim como no momento em que afasta a "alteração de finalidade original" como desvio dos objetivos de uma sociedade, a nova redação legal acertadamente determina que não haverá preconceitos em relação a desconsideração da personalidade jurídica, ratificando a força excepcional da medida. Por outro lado, PABLO STOLZE $^{47}$ defende a posição de que a "alteração de finalidade original"

\footnotetext{
${ }^{46}$ Consoante Capítulo III.2.1.

47 STOLZE, Pablo. A Medida Provisória da "Liberdade Econômica" e a Desconsideração da Personalidade Jurídica (Art. 50, CC) : Primeiras Impressões. Disponível em <http://www.flaviotartuce.adv.br/artigos_convidados>. Acesso em 13 mai. 2019.
} 
representa grande possibilidade de caracterizar desvio dos propósitos de uma sociedade, sem, contudo, detalhar seu posicionamento.

\title{
II.3.2 - ART. 28 do Código de Defesa do Consumidor - teORIA MENOR DA DESCONSIDERAÇÃO DA PERSONALIDADE JURÍDICA.
}

Por mais que o aludido art. 50 do CC tenha aplicação mais corriqueira na atividade forense, a primeira legislação a prever a teoria da desconsideração da personalidade jurídica foi o Código de Defesa do Consumidor (CDC) que, em seu art. 28 , caput e $\S 5^{\circ}$, possui a seguinte determinação:

\begin{abstract}
"Art. 28. O juiz poderá desconsiderar a personalidade jurídica da sociedade quando, em detrimento do consumidor, houver abuso de direito, excesso de poder, infração da lei, fato ou ato ilícito ou violação dos estatutos ou contrato social. A desconsideração também será efetivada quando houver falência, estado de insolvência, encerramento ou inatividade da pessoa jurídica provocados por má administração.

\section{(...)}

$\S 5^{\circ}$ Também poderá ser desconsiderada a pessoa jurídica sempre que sua personalidade for, de alguma forma, obstáculo ao ressarcimento de prejuízos causados aos consumidores."
\end{abstract}

Da leitura do texto legal, pode-se inferir que as razões supramencionadas no corrente trabalho para a desconsideração da personalidade jurídica ${ }^{48}$ são ampliadas pela lei consumerista. Assim, além da notória característica de abuso de direito, fundamental a observância aqui de outras razões para a desconsideração, tais como a descontinuidade econômica da sociedade, fruto de uma "má administração".

Nessa esteira, o que seguramente chama mais a atenção no dispositivo consumerista é a referência contida no $\S 5^{\circ}$, no qual se afirma que a desconsideração será efetivada sempre que a personalidade jurídica da sociedade devedora "for, de alguma forma, obstáculo ao ressarcimento de

\footnotetext{
${ }^{48}$ Vide Capítulo II.1.
} 
prejuízos causados aos consumidores". Trata-se de dispositivo bastante diferenciado em relação ao contido no Código Civil, o que denota uma maior incidência da aplicação do instituto em relações regidas pelo $\mathrm{CDC}$, pois não se trata aqui da presença de abuso no uso da personalidade, e sim do mero inadimplemento de uma obrigação. Assim, caso essa falta de pagamento se dê na esfera do Direito do Consumidor, o patrimônio particular do sócio da devedora já estará apto a responder pelo débito.

Esse entendimento constitui a chamada "teoria menor da desconsideração da personalidade jurídica", tendo em vista que são exigidos, nesse enquadramento de desconsideração, requisitos mais abrangentes e mais fáceis de serem alcançados se comparados ao disposto no art. 50 do CC. Assim, nota-se uma mitigação do princípio da autonomia patrimonial entre sócios e a sociedade da qual eles fazem parte. Basta, portanto, que a personalidade jurídica se configure como um obstáculo no ressarcimento de consumidores para que ocorra a desconsideração.

Ao encontro desse entendimento, o STJ já decidiu que a razão para isto reside no fato de que o risco empresarial da atividade não pode ser suportado pelo consumidor, devendo ser atingindo o patrimônio dos sócios mesmo que estes não tenham dolo em agir em fraude ou abuso da personalidade jurídica de sua sociedade. ${ }^{49}$

Nesse diapasão, os autores do anteprojeto do CDC afirmam:

"O dispositivo protege amplamente o consumidor, assegurando-lhe livre acesso aos bens patrimoniais dos administradores sempre que o direito subjetivo de crédito resultar de quaisquer das práticas abusivas elencadas no dispositivo.

$(\ldots)$

Por todo exposto, a partir do julgamento deste leading case $^{50}$, filiamo-nos à corrente que prega a aplicabilidade do $\S 5^{\circ}$ do art. 28 do CDC, por entender que nosso legislador acolheu, sem reservas, a tese do amplo espectro da desconsideração da personalidade jurídica, para aplicá-la sempre que a

${ }^{49}$ STJ, REsp 279.273/SP, Rel. Ministro Ari Pargendler, Rel. para Acórdão Ministra Nancy Andrighi, Brasília, 04 dez. 2003.

${ }^{50}$ Trata-se do resultado do julgamento do REsp 279.273/SP, no qual o STJ entendeu pela plena aplicabilidade do art. $28, \S 5^{\circ}$, CDC. 
personalidade jurídica - de alguma forma, rectius, de qualquer modo - for obstáculo ao ressarcimento dos prejuízos causados aos consumidores." ${ }^{" 51}$

Em relação a esse alargamento da possibilidade de desconsideração, FABio UlhoA COELho ${ }^{52}$ possui severa crítica, no sentido de rejeitar o alargamento da possibilidade de desconsideração, uma vez que a retirada do véu da personalidade jurídica da sociedade só se justificaria em casos de abuso de direito ou enfrentamento de fraudes, em respeito à própria definição doutrinária de pessoa jurídica. Segundo o doutrinador, caso fosse dada interpretação ampliativa da "disregard doctrine" em todos os casos no ramo consumerista, estar-se-ia a afastar o texto do caput do art. 28 do CDC e até mesmo não haveria que se falar em pessoa jurídica para o Direito do Consumidor.

No que pese o referido comentário acerca do dispositivo, se faz razoável a ratio legis a qual o art. $28, \S 5^{\circ}, \mathrm{CDC}$, se pretende, eis que notória a hipossuficiência do consumidor em processos de alçada consumerista. Nesse sentido, deve-se prestigiar a ampliação das possibilidades de ressarcimento da parte menos favorecida nesse ramo do Direito. Caso contrário, não haveria razão para existir essa proteção especial conferida pelo legislador.

Essa questão é corroborada pela própria lógica do CDC. Esse diploma legal, ao conferir às pessoas jurídicas uma responsabilidade objetiva, independente de culpa, deu respaldo a uma possibilidade de desconsideração da personalidade jurídica igualmente objetiva, sem que os sócios ou administradores tenham a intenção de fraudar ou abusar do direito que a lei conferiu à existência de pessoas jurídicas.

\footnotetext{
${ }^{51}$ GRINOVER, Ada et al.. Código brasileiro de defesa do consumidor: comentado pelos autores do anteprojeto, vol I. Direito Material (arts. $1 .^{\circ}$ a 80 e 105 a 108). 10 ed. revista, atualizada e reformulada - Rio de Janeiro: Forense, 2011. p. 253-258.

${ }^{52}$ COELHO, Fabio. 2011. p. 71-72.
} 


\section{II.3.3 - OUTRAS DISPOSIÇÕES DE DIREITO MATERIAL SOBRE A POSSIBILIDADE DE DESCONSIDERAÇÃO.}

Além dos dois notórios dispositivos acima analisados, a "disregard doctrine" também se faz presente em outras legislações ao longo do nosso ordenamento jurídico pátrio.

Conforme já mencionado linhas acima, o art. 34 da Lei 12.529/2011 ${ }^{53}$ disciplina a possibilidade de levantamento do véu da pessoa jurídica quando houver prática de atos infringentes à ordem econômica, sendo obrigatórios alguns requisitos, como "abuso de direito, excesso de poder, infração da lei, fato ou ato ilícito ou violação dos estatutos ou contrato social." Já o seu parágrafo único completa essa ideia, ao dispor que "[a] desconsideração também será efetivada quando houver falência, estado de insolvência, encerramento ou inatividade da pessoa jurídica provocados por má administração". Ou seja, o que se tem nessa disposição de direito concorrencial é a exata reprodução do art. 28, caput, do CDC, alargando as possibilidades de desconsideração da personalidade jurídica em relação a uma hipotética situação da concorrência desleal entre agentes econômicos, afastando, por consequência, a aplicação das regras mais rígidas do art. 50, CC.

De abrangência ainda mais evidente é a possibilidade de desconsideração da personalidade jurídica de uma sociedade quando esta comete infração ambiental. Assim conclui-se pela leitura do art. $4^{\circ}$, da Lei 9.605/98, que trata de sanções penais e administrativas decorrente de atos e práticas nocivas ao meio-ambiente, em mais uma aplicação da teoria menor da desconsideração da personalidade jurídica. O mencionado dispositivo determina que “[p]oderá ser desconsiderada a pessoa juridica sempre que sua personalidade for obstáculo ao ressarcimento de prejuízos causados à qualidade do meio ambiente”.

\footnotetext{
${ }^{53} \mathrm{O}$ referido artigo pode ser encontrado reproduzido na nota de rodapé $n^{\circ} 24$.
} 
Em precisa lição sobre o tema, NiCOLAO DinO DE CASTRO COSTA Neto, Ney de Barros Bello Filho e Flávio Dino de Castro Costa explicam a ratio legis da norma:

\begin{abstract}
"O sentido é responsabilizar pessoalmente as pessoas físicas que agem por detrás das pessoas jurídicas, agredindo seus patrimônios e rompendo com o mito da intangibilidade da pessoa jurídica e da autonomia de seus bens, nas questões atinentes aos danos perpetrados contra o ambiente pela empresa.

O mito da não confusão entre o patrimônio da pessoa jurídica e o da pessoa física tem acarretado inúmeros atentados ao ambiente, sem qualquer compensação ou indenização, exatamente porque a personalidade diferenciada funciona como escudo ante a investida do Estado com o fito de repor parcialmente o patrimônio agredido.
\end{abstract}

Esse escudo pode ser enfim trespassado quando o Estado desconhece que o ato danoso foi praticado por uma pessoa jurídica e agride o patrimônio da própria pessoa física que gerencia, dirige e determina os destinos da empresa" ${ }^{, 54}$

Assim, percebe-se uma larga aplicação da "disregard doctrine" em nosso direito pátrio, que tem sido aceita por este corriqueiramente, em maior ou menor grau de abrangência de seus requisitos.

\title{
II.3.4 - DESCONSIDERAÇÃo INVERSA DA PERSONALIDADE JURÍDICA.
}

A desconsideração da personalidade jurídica até aqui discorrida no presente trabalho, qual seja, aquela oriunda de afastamento da personalidade da pessoa jurídica para incursão no patrimônio dos sócios, não é única possível dentro da "disregard of legal entity".

Nessa esteira, se revela de grande aceitação no direito pátrio a chamada desconsideração inversa da personalidade jurídica. Nesta, diferentemente do que ocorre corriqueiramente, é o sócio que, por inadimplemento de obrigação pessoal, terá sua personalidade jurídica desconsiderada, respondendo o patrimônio da sociedade pelo indébito.

\footnotetext{
${ }^{54}$ COSTA NETO, Nicolao Dino de Castro; BELLO FILHO, Ney de Barros; COSTA, Flávio Dino de Castro. Crimes e Infrações Administrativas Ambientais: comentários à Lei n. ${ }^{\circ}$ 9.605/98. $2^{\mathrm{a}}$ edição rev. e atual. Brasília: Brasília Jurídica, 2001. p. 76.
} 
De acordo com FREDIE DIDIER JR.$^{55}$, o melhor exemplo ilustrativo da aludida possibilidade se encontra no âmbito do direito de família, uma vez que uma pessoa física, tendo débitos a honrar com seu antigo companheiro, esconde valores na sociedade da qual é sócia, esvaziando seu patrimônio pessoal propositadamente. Nesses casos, é legítimo que o patrimônio da pessoa jurídica responda por dívida daquele que compõe seus quadros societários, tendo em vista a cristalina ocorrência de confusão entre os patrimônios do sócio e da sociedade, com claro desvio de finalidade desta.

${ }^{55}$ DIDIER JR., Fredie. Curso de direito processual: introdução ao direito processual civil, parte geral e processo de conhecimento. v.1. 17. ed. - Salvador: JusPodivm, 2015. p. 520. 


\section{Capítulo III - Procedimento de Desconsideração da Personalidade Jurídica.}

A desconsideração da personalidade jurídica, consoante demonstração exaustiva realizada no presente trabalho, possui um caráter extremamente episódico e pontual, uma vez que a regra contumaz de autonomia patrimonial da sociedade em relação aos seus sócios torna a medida notadamente excepcional. Em função dessa característica, fez-se necessário o surgimento de um novo procedimento para a aplicação do instituto, o qual se denominou Incidente de Desconsideração da Personalidade Jurídica (arts. 133 a 137, CPC/15), o qual garante, conforme será visto, um atendimento muito mais rico dos direitos dos sócios, tais como a ampla defesa, contraditório e devido processo legal, mas que também apresenta inconsistências.

Contudo, antes de adentrar de uma vez no novo instituto processual, configura-se necessária uma breve consideração acerca de como se realizava o procedimento de desconsideração da personalidade jurídica no regime anterior ao atual Código de Processo Civil.

\section{III.1 - Breve Panorama Pré-CPC/15.}

Antes do advento do $\mathrm{CPC} / 15$, não havia nenhuma norma de direito processual apta a reger o procedimento para a desconsideração da personalidade jurídica ${ }^{56}$. O Incidente de Desconsideração da Personalidade Jurídica, portanto, inovou em matéria processual algo que já era regrado pelo direito material, conforme visto. Nesse passo, é importante destacar que um instituto de tamanha excepcionalidade como a desconsideração da personalidade jurídica não poderia estar furtado de um procedimento que lhe assegurasse uma aplicação criteriosa.

${ }^{56}$ GAMA, Guilherme Calmon Nogueira da. Incidente de Desconsideração da Personalidade Jurídica. Em: Revista de Processo. ano 41. vol. 262. dez, 2016. p. 65. 
Em aparente discordância a essa posição, lecionando na vigência do CPC/73, GILBERTO GOMES BRUSCHI afirmava:

"Partindo da idéia de um processo efetivo e sem morosidade excessiva, chega-se à execução onde o exequente constata não mais existirem bens capazes de satisfazer o crédito a que tem direito. Sabendo que foram levados a efeito certos atos contrários aos ditames legais pela sociedade executada, basta que comprove tais fatos, requerendo ao juiz que proceda à desconsideração da personalidade jurídica da empresa executada, visando apenas e tão somente à ineficácia dos atos exercitados irregularmente, ensejando o acesso aos bens daquele que os praticou para que se satisfaça a execução.

Ou seja, não há por que ajuizar processo paralelo autônomo para, somente após o trânsito em julgado da sentença deste, haver a constrição dos bens de terceiros responsáveis pelos atos ilícitos.

Não há que falar em violação do contraditório ao desconsiderar a personalidade jurídica por decisão interlocutória, já que este será postergado para o momento em que o terceiro se rebele contra tal pronunciamento judicial.

(...)

Uma vez requerida e admitida pelo juízo a desconsideração e sendo ela deferida, é necessária a intimação do sócio e/ou do administrador da sociedade para que tomem ciência da decisão que os responsabilizou subsidiariamente pela obrigação contraída pela sociedade.

$(\ldots)$

De convir que é perfeitamente possível e correto o juiz examinar de maneira superficial as provas, trazidas pelo exequente e que embasaram seu pedido para desconsiderar a personalidade jurídica do executado, por mera decisão interlocutória, fazendo ou não com que se tornem passíveis de penhora os bens das pessoas naturais ou mesmo de outras pessoas jurídicas, que constituem a executada primitiva." $" 57$

Esse tipo de visão apenas colabora para um desatendimento aos direitos básicos dos sócios de uma sociedade, como o principio da autonomia patrimonial, sendo desrespeitado ainda seu direito constitucional a um devido processo legal (art. $5^{\circ}$, LIV, CRFB/ $88^{58}$ ).

Analisando esse "contencioso diferido" ao sócio no regime anterior ao novo Código de Processo Civil, DANIEL AMORIM ASSUMPÇÃO NEVES afirma que a prática de não se permitir que aqueles que seriam incluídos em um

\footnotetext{
${ }^{57}$ BRUSCHI, Gilberto Gomes. Aspectos processuais da desconsideração da personalidade jurídica. $2^{a}$ ed. - São Paulo: Saraiva, 2009. p. 87-100.

${ }^{58}$ Constituição da República Federativa do Brasil de 1988, art. 5: " LIV - ninguém será privado da liberdade ou de seus bens sem o devido processo legal;"
} 
processo (em virtude de desconsideração da personalidade jurídica) se defendam plenamente, nem sempre era acolhida pelo STJ. Entretanto, segundo o autor, isso poderia ser justificado em razão do poder geral de cautela do juiz. ${ }^{59}$

Na mesma toada contrária aos direitos processuais mais básicos dos litigantes, sob a ótica do CPC/73, GUSTAVO BANDEIRA informa:

"Ressalte-se, por fim, que referido procedimento, de permitir que os efeitos da execução recaia sobre os bens do sócio, em nada agride o princípio do contraditório e da ampla defesa, na medida em que, em tais casos, poderá o mesmo se valer da medida apropriada para a defesa do seu patrimônio e impugnação da sua responsabilização patrimonial decorrente da desconsideração, utilizando-se dos embargos de devedor, muito embora não seja ele, tecnicamente, devedor, mas responsável." 60

Outrossim, quando não se condicionava a desconsideração a uma ampla cognição, regida pelo procedimento comum ${ }^{61}$, havia a defesa de que condicionar a decretação da desconsideração da personalidade jurídica a uma sentença, apenas contribuiria para a perda da efetividade do instituto. Para os defensores dessa tese, a demora na aplicação da resolução da questão não poderia ocorrer caso o demandante trouxesse aos autos provas ou até mesmo indícios de fraude, situação na qual a desconsideração poderia ser decretada de plano pelo juiz ${ }^{62}$.

Novamente, caso isso fosse realizado, os sócios da sociedade acusados de proceder com seus negócios mediante abuso de direito ou fraude patrimonial ficariam absolutamente podados de seus direitos fundamentais de cunho processual.

Conforme assenta José Miguel GARCiA MedinA ${ }^{63}$, o fato do novo regime trazido pelo $\mathrm{CPC} / 15$ clamar pela citação de terceiro alheio ao

\footnotetext{
${ }^{59}$ NEVES, Daniel Amorim Assumpção. Manual de Direito Processual Civil. 8. Ed - Salvador: JusPodivm, 2016. p. 311.

${ }^{60}$ BANDEIRA, Gustavo. Relativização da Pessoa Jurídica. Niterói, RJ: Impetus, 2004. p. 142.

${ }^{61}$ Conforme Capítulo III.3.

${ }^{62}$ BRUSCHI, Gilberto Gomes. 2009. p. 101.

${ }^{63}$ MEDINA, José Miguel Garcia. Novo código de processo civil comentado : com remissões e notas comparativas ao CPC/1973. 4. ed. rev., atual. e ampl. São Paulo: Revista dos Tribunais, 2016. p. 242.
} 
processo principal para que responda à inquisição da desconsideração da personalidade jurídica da pessoa da qual ele é sócio deve ser prestigiada, por valorizar justamente o direito fundamental ao contraditório.

Outrossim, esse objetivo proposto pelo IDPJ foi bem delineado por MAURÍCIO ANTONIO TAMER:

"Até a vigência do $\mathrm{CPC} / 15$, inexistia no ordenamento jurídico brasileiro procedimento específico para que fosse realizada a desconsideração da personalidade jurídica. Faltava, portanto, um padrão procedimental a ser adotado.

Resultado disso, a aplicação da teoria da desconsideração se dava de forma casuística, gerando obstáculos e prejuízos de diferentes ordens, como a dificuldade à própria satisfação do crédito e, principalmente, a privação de bens de terceiros sem a correta observância do devido processo legal, em especial do contraditório." ${ }^{64}$

Vindo, portanto, a atender esses anseios por uma melhor abordagem processual da questão da desconsideração da personalidade jurídica, o $\mathrm{CPC} / 15$ trouxe ao ordenamento jurídico pátrio o Incidente de Desconsideração da Personalidade Jurídica, demonstrando extrema cautela para uma incidência cuidadosa de tão casuística prática, conforme será visto a seguir.

\section{III.2 - Incidente de Desconsideração da Personalidade Jurídica: ANÁlise Pormenorizada doS ARTS. 133 A 137 do CPC/15.}

O Incidente de Desconsideração da Personalidade Jurídica veio regido, no CPC/15, entre os arts. 133 e 137 do códex. Foi inserido, portanto, no Título III ("Intervenção de Terceiros") do Livro III ("Sujeitos do Processo"), sendo constituído pelo Capítulo IV desse segmento. Essa classificação, ressalta-se, se faz absolutamente apropriada, uma vez que o IDPJ possui a pretensão de incluir mais pessoas no polo passivo de uma ação já ajuizada ou em concomitância à sua proposta, sendo que essas mesmas

\footnotetext{
${ }^{64}$ TAMER, Maurício Antonio. Pontos sobre a Desconsideração da Personalidade Jurídica no Código de Processo Civil de 2015: Conceitos, Posição do Requerido e outros Aspectos Processuais. Em: Revista Brasileira de Direito Comercial, v. 11, jun./jul. 2016, p. 12.
} 
pessoas se configuram como terceiros na relação jurídica ensejadora do litígio. Ressalta-se que o fato de haver possibilidade de requerer a inclusão de pessoas no polo passivo de modo contemporâneo à propositura da ação não tem o condão de retirar a característica de terceiros delas, uma vez que se qualificam desse modo em relação à relação jurídica original entre o proponente da ação e seu ex adverso.

Ademais, conforme será demonstrado, o IDPJ possui certas características que podem influir em seu possível enquadramento em uma natureza jurídica de ação, tendo em vista sua característica de ampla cognição, regida pelo procedimento comum, dentro da categoria de Intervenção de Terceiros.

\section{III.2.1 - ART. 133.}

$\mathrm{O}$ art. 133 apresenta o instituto do IDPJ e possui a seguinte redação:

“Art. 133. O incidente de desconsideração da personalidade jurídica será instaurado a pedido da parte ou do Ministério Público, quando lhe couber intervir no processo.

$\S 10 \mathrm{O}$ pedido de desconsideração da personalidade jurídica observará os pressupostos previstos em lei.

§ 2o Aplica-se o disposto neste Capítulo à hipótese de desconsideração inversa da personalidade jurídica."

Da observação do dispositivo inaugural do instituto, fica evidente a necessidade de interesse de agir por parte de quem pretende a desconsideração. Essa constatação é um tanto óbvia a partir da lembrança de que o interesse de agir se mostra como uma das condições para a ação existir, consoante art. 17, $\mathrm{CPC} / 15^{65}$.

De igual modo, percebe-se que o incidente pode ser instaurado pedido do Ministério Público, quando lhe couber intervir no processo. A atuação do

\footnotetext{
${ }^{65}$ Código de Processo Civil de 2015, art. 17: "Para postular em juízo é necessário ter interesse e legitimidade."
} 
parquet, contudo, deve estar relacionada às ações em que ele atue como demandante, tendo em vista que, conforme lembra muito bem FLÁvio LUIZ YARSHELL ${ }^{66}$, o patrocínio do Ministério Público a questões patrimoniais privadas é extremamente contrário à $\mathrm{CFRB/88}$. Não poderia, portanto, procuradores do Ministério Público atuarem em favor de beneficiários privados do recebimento de quantias pecuniárias, sendo vedado que se emita opinio juris sobre esse fato, tendo o Enunciado $\mathrm{n}^{\circ} 123$ do FPPC $^{67}$ corroborado essa ideia.

Ainda na seara da legitimidade ativa para o pedido de desconsideração, nota-se com afinco a ausência de menção na lei à possibilidade de que o magistrado declare de ofício a desconsideração da personalidade jurídica. Em regime processual anterior, por mais que houvesse quem defendesse essa possibilidade ${ }^{68}$, a falta de previsão no atual regimento processual frustrou a aludida hipótese. Além disso, conforme lembra JESUALDO EDUARDO DE ALMEIDA JUNIOR ${ }^{69}$, a desconsideração é medida que clama pelo pedido expresso da parte interessada, sendo assim, impossível a determinação ex officio da aplicação do remédio. Consoante ressaltado por HELENO RIBEIRO NUNES FILHO ${ }^{70}$, isto ocorre mesmo em casos de aplicação da teoria menor da desconsideração da personalidade jurídica que, diferentemente do que dispõe o art. 50 do CC, não clama expressamente pelo requerimento da parte interessada -, tendo em vista que o CPC/15 estabeleceu rigoroso procedimento para a aplicação da "disregard doctrine".

\footnotetext{
${ }^{66}$ YARSHELL, Flávio Luiz. Comentários aos arts. 133 a 137. Em: CABRAL, Antonio do Passo; CRAMER, Ronaldo (Coords.). Comentários ao novo código de processo civil. 2. ed. rev. atual. e ampl. Rio de Janeiro: Forense, 2016. p. 233-234.

${ }^{67}$ Enunciado n ${ }^{\circ} 123$ do Fórum Permanente de Processualistas Civis: “(art. 133) É desnecessária a intervenção do Ministério Público, como fiscal da ordem jurídica, no incidente de desconsideração da personalidade jurídica, salvo nos casos em que deva intervir obrigatoriamente, previstos no art. 178. (Grupo: Litisconsórcio e Intervenção de Terceiros)".

${ }^{68}$ MARTINS, Fran. 2008. p. 196.

${ }^{69}$ ALMEIDA JUNIOR, Jesualdo Eduardo de. O Incidente de Desconsideração da Personalidade Jurídica das Pessoas Jurídicas no Novo CPC. Em: Revista dos Tribunais. ano 105. vol. 974. dez, 2016. p. 295.

${ }^{70}$ FILHO, Heleno Ribeiro Nunes. A Desconsideração da Personalidade Jurídica à luz do incidente processual trazido pelo novo Código de Processo Civil brasileiro. Em: Revista de Processo. ano 41. vol. 258. ago., 2017. p. 111-117.
} 
Pensar diferentemente seria, na visão do autor, cristalina violação ao princípio da inércia da jurisdição.

Por fim, o $\S 2^{\circ}$ reforça a ideia da possibilidade de desconsideração inversa da personalidade jurídica, que ocorre quando o sócio possui dívidas pessoais contra si e utiliza da sociedade para fraudá-las. Essa previsão, conforme já elaborado no Capítulo II.3.4 do presente trabalho, é uma possibilidade amplamente aceita pela doutrina pátria. Assim, não se vê com tamanha necessidade a inclusão desse dispositivo, eis que apenas confirma algo já pacífico em nosso Direito.

\section{III.2.2 - ART. 134.}

O art. 134 é de importância notável, tendo em vista que ele delimita o momento inicial do IDPJ, o que deve ser arguido quando a parte pretende fazer uso desse expediente e os seus efeitos imediatos para o processo:

\footnotetext{
“Art. 134. O incidente de desconsideração é cabível em todas as fases do processo de conhecimento, no cumprimento de sentença e na execução fundada em título executivo extrajudicial.

$\S 1$ o A instauração do incidente será imediatamente comunicada ao distribuidor para as anotações devidas.

§ 2o Dispensa-se a instauração do incidente se a desconsideração da personalidade jurídica for requerida na petição inicial, hipótese em que será citado o sócio ou a pessoa jurídica.

§ 3o A instauração do incidente suspenderá o processo, salvo na hipótese do § 20.

$\S 4$ o O requerimento deve demonstrar o preenchimento dos pressupostos legais específicos para desconsideração da personalidade jurídica."
}

Primeiramente, importante ressaltar que o IDPJ é cabível em todas as fases do processo, passando pelo procedimento comum, e alcançando a fase executória, tanto aquela embasada por título executivo judicial quanto aquela provocada por título executivo formado extrajudicialmente, além da possibilidade de instauração do incidente diretamente perante Tribunais, o 
que é reforçado pelo disposto no art. 932, VI, $\mathrm{CPC} / 15^{71}$. Isto é relevante porque, no regime anterior ao novo Código de Processo Civil, era muito comum que a incidência patrimonial do sócio ocorresse apenas após a constituição de um título executivo. Daí dizer que não haveria ofensa à ampla defesa e contraditório, porque o sócio poderia se defender opondo embargos de terceiro. Pelas novas regras, com previsão expressa de a desconsideração poder ocorrer a qualquer momento, se faz ainda mais necessária a previsão de um procedimento de ampla cognição antes da incidência no patrimônio dos sócios da pessoa a ser desconsiderada.

Ademais, a instauração do incidente, conforme acentua o $\S 1^{\circ}$, deverá ser imediatamente comunicada ao distribuidor para as anotações devidas. Isto decorre do fato de que o IDPJ forma novos autos processuais, com um novo número na Comarca em que é instaurado, ainda que ele tramite apenso ao seu processo principal. Como a pretensão, no IDPJ, é de expansão de um dos polos da ação, esse dispositivo veio como forma de atender ao princípio da publicidade processual, dando notícia a possíveis interessados da instauração desse procedimento. ${ }^{72}$

Não haverá, porém, necessidade de instauração do IDPJ se o pedido de desconsideração for feito já na petição inicial do processo principal. É o que prevê o $\S 2^{\circ}$, que dispensa o instituto nessa hipótese. Conforme relembra DANIEL AMORIM ASSUMPÇÃO NEVES ${ }^{73}$, trata-se uma exceção, uma vez que o art. $795, \S 4^{\circ}, \mathrm{CPC} / 15^{74}$, prevê a obrigatoriedade da observação do IDPJ para que a desconsideração se efetive.

Na seara dessa excepcionalidade, a questão da desconsideração será decidida por sentença, da qual caberá recurso de Apelação, e não pela decisão

\footnotetext{
${ }^{71}$ Código de Processo Civil de 2015, art. 932: "“Incumbe ao relator: (...) VI - decidir o incidente de desconsideração da personalidade jurídica, quando este for instaurado originariamente perante o tribunal;"

${ }^{72}$ YARSHELL, Flávio Luiz. 2016. p. 235.

${ }^{73}$ NEVES, Daniel Amorim Assumpção. 2016. p. 308.DANIEL ASSUMPÇÃO, P. 308

${ }^{74}$ Código de Processo Civil de 2015, art. 795: "Os bens particulares dos sócios não respondem pelas dividas da sociedade, senão nos casos previstos em lei. (...) § $4^{\circ}$ Para a desconsideração da personalidade jurídica é obrigatória a observância do incidente previsto neste Código."
} 
interlocutória prevista no art. 136, CPC/15 7576 . Não se cogita, nessa hipótese, que a decisão acerca da desconsideração seja tomada em momento diverso daquele em que se decidirá o pedido principal do processo. Isto se observa em função do princípio da prejudicialidade: caso a demanda principal seja rejeitada, não poder-se-ia falar acerca de responsabilidade patrimonial de terceiro. Nada obstante, caso o juiz já esteja convicto acerca de seu convencimento, é prudente que a tome o mais rápido possível, sendo, nesses casos, admissível a desconsideração anteriormente à sentença final, o que será feito por decisão interlocutória, mesmo que o pedido tenha sido feito na inicial. $^{77}$

Além disso, a desconsideração realizada por sentença, conforme será visto nos Capítulos III.4.1 e III.4.2, implicará em diferenças de abordagem na questão de sustentação oral nos recursos em cada caso e, ainda, na percepção de honorários dos advogados dos demandados em cada uma das situações.

Outrossim, o pedido de desconsideração da personalidade jurídica, conforme acentua FREDIE DIDIER JR. ${ }^{78}$, pode ser autônomo, com uma ação unicamente com o escopo de realizar a desconsideração, sem cumulação de pedidos ou litisconsórcio passivo.

Ademais, o dispositivo ora comentado afirma determinados efeitos da instauração do IDPJ. Um deles é a suspensão do processo principal ao incidente instaurado, conforme previsão do $\S 3^{\circ}$, o que não ocorrerá quando a desconsideração for requerida na petição inicial. Nesse passo, a doutrina assente que a suspensão aqui tratada possui natureza imprópria, uma vez que a paralisação do processo se dá apenas na parte atinente à desconsideração.

\footnotetext{
${ }^{75}$ DIDIER JR., Fredie. Curso de direito processual: o processo civil nos tribunais, recursos, ações de competência originária de tribunal e querela nullitatis. v.3. 13. ed. - Salvador: JusPodivm, 2016. p. 218.

${ }^{76}$ THEODORO JÚNIOR, Humberto. Curso de Direito Processual Civil - Teoria geral do direito processual civil, processo de conhecimento e procedimento comum - vol. 1. 57. ed. rev., atual. e ampl. - Rio de Janeiro: Forense, 2016. p. 404.

${ }_{77}$ TAMER, Maurício Antonio. 2016. p. 15-16.

${ }^{78}$ DIDIER JR., Fredie. 2015. p. 520.
} 
Não haveria que se falar, portanto, em suspensão total do processo. Nesse sentido, FLÁvio LUIZ YARSHELL ${ }^{79}$ faz uma analogia com o fato de que o cumprimento provisório de sentença não impede atos de constrição do patrimônio do devedor. Desse modo, ele argumenta que não haveria porque IDPJ impedir tais atos também.

Concordando de modo simples com esse entendimento, JOSÉ MIGUEL GARCIA MEDINA pontua:

"[n]ão nos parece acertado suspender-se todo o processo, em razão da instauração do incidente. Mais adequado cingir-se eventual suspensão à questão da desconsideração - nada impedindo a prática de outros atos executivos, por exemplo, no curso do procedimento" 80

Nada obstante, importante lembrar que, ao instaurar um IDPJ, o demandante pretende incluir no polo passivo da demanda novos sujeitos que, mediante prova no processo, serão igualmente responsabilizados pelo pagamento do débito cobrado. Isto se revela algo muito sério para que sejam realizados, normalmente, certos atos processuais. Nesse sentido, uma pretensão de realizar constrição de bens do responsável principal pode ser válido. Entretanto, outros movimentos processuais, tais como produção de provas, por exemplo, se feitos à revelia de alguém que pode futuramente entrar no processo, podem gerar consequências desagradáveis, como a possível anulação deles. Assim, deve-se ver com cautela os limites dessa suspensão, porque, de alguma forma, são inúmeros os atos processuais que podem ser praticados conflitando interesse de alguém que, futuramente, pode vir a fazer parte do processo.

Esse cuidado, reforça-se, foi tomado pelo legislador na redação do $\S$ $4^{\circ}$ do dispositivo ora em comento. Ele determina que aquele que pretende desconsiderar a personalidade jurídica do demandado deve comprovar todos os requisitos legais para que tal fenômeno aconteça. Nesse caso, não está se falando apenas no art. 50, $\mathrm{CC}$, com seus requisitos objetivos e subjetivos,

\footnotetext{
${ }^{79}$ YARSHELL, Flávio Luiz. 2016. p. 236.

${ }^{80}$ MEDINA, José Miguel Garcia. 2016. p. 242.
} 
conforme delineado no Capítulo II.3.1. A questão concernente aqui é o atendimento aos pressupostos legais de possibilidades de desconsideração, conforme a legislação material que rege a situação. Portanto, caso se esteja diante de situações que abrangem a teoria menor da desconsideração da personalidade jurídica, como as previstas nas legislações consumerista e ambiental $^{81}$, não haverá necessidade de comprovação de fraude ou abuso de direito, mas tão somente de dificuldade experimentadas pelo credor em obter seu pagamento devido.

Apresentando uma possível incorreção no referido parágrafo, DANIEL AMORIM ASSUMPÇÃO NEVES afirma que a previsão delineada por esse dispositivo "pode passar a equivocada impressão de que o requerente terá que apresentar prova pré-constituída e liminarmente demonstrar o cabimento da desconsideração" ${ }^{82}$ Porém, o próprio autor evidencia que não se deve provar logo no começo os motivos para desconsideração, mas tão somente apresentar indícios de sua existência, tendo em vista que, conforme se verá a seguir, o procedimento do IDPJ, em sua completude, clama por uma intensa instrução probatória. Inclusive, quaisquer pedidos genéricos de desconsideração da personalidade jurídica no bojo do incidente ora comentado, tais como fundamentar-se na dignidade da pessoa humana, podem levar à inépcia da petição inicial do IDPJ $^{83}$.

\section{III.2.3 - ART. 135.}

$\mathrm{O}$ art. 135 traz a regra no que diz respeito à modalidade de intimação do demandado para que apresente resposta ao incidente, assim como possui regras sobre a instrução processual a ser realizada no procedimento em apreço:

\footnotetext{
${ }^{81}$ Consoante abordado nos Capítulos II.3.2 e II.3.3, respectivamente.

${ }^{82}$ NEVES, Daniel Amorim Assumpção. 2016. p. 310.

${ }^{83}$ DIDIER JR., Fredie. 2015. p. 520.
} 
"Art. 135. Instaurado o incidente, o sócio ou a pessoa jurídica será citado para manifestar-se e requerer as provas cabíveis no prazo de 15 (quinze) dias."

Em primeiro lugar, chama atenção a redação do dispositivo legal em relação ao requerimento de provas. De sua mera leitura, é possível inferir que as provas a serem produzidas no IDPJ devem ser requeridas apenas pelo demandado quando da oportunidade de apresentação de sua defesa.

Entretanto, partindo do pressuposto da ampla cognição necessária para a resolução do incidente ${ }^{84}$, se faz fundamental que o demandante também indique quais provas pretende produzir no momento em que realize a propositura do IDPJ, sob pena de ferir a necessária igualdade entre as partes em um processo.

Essa atitude visa, no mínimo, a adoção de uma cautela que tem como escopo evitar a preclusão desse direito para o demandante. Como a cognição é exauriente no IDPJ, a máxima produção de provas busca uma melhor resolução do litígio.

Além disso, o dispositivo ora comentado traz a regra de intimação para que o demandado apresente sua defesa. Ele exige a citação daqueles que poderão ser incluídos no processo como responsáveis pelo débito. É essa regra de citação que garante o atendimento à ampla defesa e ao contraditório dos demandados, uma vez que lhes dá a oportunidade de questionar todos os argumentos levantados pelo demandante que possam levar à desconsideração da personalidade jurídica da pessoa jurídica da qual eles são sócios ou a inclusão da pessoa jurídica não atuante no processo, nos casos de desconsideração inversa.

Outrossim, esse regramento não é desprovido de sentido, uma vez que se busca chamar alguém para que integre um processo do qual não faz parte,

${ }^{84}$ CÂMARA, Alexandre de Freitas. O novo processo civil brasileiro. 2 ed. - São Paulo: Atlas, 2016. p. 101. 
que é justamente a função da citação, conforme art. $238, \mathrm{CPC} / 15^{85}$. Inclusive, faz sentido que o texto traga as expressões "sócio" e "pessoa jurídica", justamente em sintonia com o art. 133, $\S 2^{\circ}, \mathrm{CPC} / 15$, que prevê a possibilidade de desconsideração inversa da personalidade jurídica. Ou seja, dependendo da situação, estar-se-ia a citar o sócio ou a sociedade sócia de uma pessoa física, ambas não pertencentes ao processo principal do qual o incidente é anexo.

Porém, não se revela difícil imaginar que o demandante de um IDPJ possa escolher colocar, em seu polo passivo, aquele sócio ou sociedade que, originariamente, faz parte do processo principal. No que pese a opinião de FLÁVIO LUIZ YARSHELL ${ }^{86}$, para quem a sociedade principal não deve fazer parte do requerimento de desconsideração, possuindo esta apenas mero interesse jurídico na demanda desconsiderativa, configura-se como uma faculdade de quem instaura o IDPJ a montagem de seu polo passivo, o que inclui a possível inserção do réu do processo principal na demanda incidente, o qual, por formar autos novos (consoante art. $\left.134, \S 1^{\circ}, \mathrm{CPC} / 15\right)$, possibilita um polo passivo independente.

Sobre a legitimidade de defesa daquela pessoa, sociedade ou sócio, que poderá vir a ter sua personalidade jurídica desconsiderada, FREDIE DIDIER JR. afirma:

"Há precedente do STJ que reconhece à pessoa jurídica legitimidade recursal para impugnar a decisão que desconsidera a sua personalidade (STJ, REsp n. 1.421.464SP, rel. Min. Nancy Andrighi, j. 24.04.2015). Para tanto, tem a pessoa jurídica de defender a sua regular administração e a sua autonomia, sem se imiscuir indevidamente na esfera dos direitos dos sócios ou administradores." ${ }^{\$ 7}$

Diante dessa possibilidade de formação de um litisconsórcio facultativo, surge uma questão delicada. Afinal, como será possível citar a sociedade ou sócio no IDPJ, em situações em que eles já constem também no

\footnotetext{
${ }^{85}$ Código de Processo Civil de 2015, art. 238: "Citação é o ato pelo qual são convocados o réu, o executado ou o interessado para integrar a relação processual."

${ }^{86}$ YARSHELL, Flávio Luiz. 2016. p. 237.

${ }^{87}$ DIDIER JR., Fredie. 2015. p. 521.
} 
polo passivo do processo principal a esse incidente? Tal questionamento se mostra inteiramente válido, tendo em vista que a citação é o chamamento ao processo, e o réu da ação principal já consta no processo como um todo. Desse modo, seria tecnicamente errado "citar" a parte nessa situação, tendo em vista que ela já conhece o processo em sua íntegra.

Entretanto, para além dessa mera formalidade, surge outra questão com repercussões mais relevantes para o ramo do Direito ora estudado, qual seja, o prazo para resposta do demandado que, a despeito de já estar citado no processo principal, também deverá ser "citado" na demanda incidental. Seguindo esse raciocínio, como, então, ficaria seu prazo para apresentar resposta?

Nesse passo, não se pode perder de vista que os sócios (ou, sempre se relembre, a sociedade nos casos de desconsideração inversa) que devem ser citados por IDPJ poderão sê-lo por quaisquer uma das modalidades previstas no art. $246, \mathrm{CPC} / 15^{88}$. A citação, como ato processual objetivo e técnico, deve cumprir essas formalidades, sob pena de ineficácia do procedimento. Assim, devem ser descartadas quaisquer hipóteses de começo de prazo para resposta, em relação à sociedade já constante no processo principal, que visam estabelecer o dia inicial de prazo como aquele da publicação da decisão que ordena a sua citação. Adentrar nessa hipótese seria, portanto, faltar com o rigor processual que esse procedimento exige.

A solução, portanto, seria uma daquelas que podem ser conferidas em circunstâncias de litisconsórcio passivo: o prazo para resposta deve ser comum a todos os corréus, a partir da concretização da citação do último a ser citado, de modo a garantir isonomia em seu tratamento, sem que haja supressão de tempo para apresentação de defesa para quaisquer um dos demandados. Essa saída processual garante, ainda, maior segurança jurídica

\footnotetext{
${ }^{88}$ Código de Processo Civil de 2015, art. 246: “A citação será feita: I - pelo correio; II - por oficial de justiça; III - pelo escrivão ou chefe de secretaria, se o citando comparecer em cartório; IV - por edital; $V$ - por meio eletrônico, conforme regulado em lei."
} 
para aquele já figurante na demanda principal, uma vez que delimita, com precisão, quando se inicia seu prazo para apresentação de resposta.

\section{III.2.4 - ART. 136.}

$\mathrm{O}$ art. 136 versa sobre a modalidade de resolução do IDPJ, bem como sua possibilidade recursal nos casos em for apresentado diretamente nos tribunais:

“Art. 136. Concluída a instrução, se necessária, o incidente será resolvido por decisão interlocutória.

Parágrafo único. Se a decisão for proferida pelo relator, cabe agravo interno.”

Da mera leitura, é possível constatar que o referido dispositivo não tratou da modalidade recursal dessa decisão interlocutória que resolve o IDPJ. Felizmente, o CPC/15 não deixou dúvidas em relação a esse ponto: o recurso cabível contra decisão interlocutória que resolve o IDPJ é o Agravo de Instrumento, por disposição expressa do art. 1.015, IV, CPC/15 ${ }^{89}$. Desse modo, no caso específico do IDPJ, ficam superadas quaisquer divergências jurídicas acerca do cabimento taxativo ou exemplificativo do Agravo de Instrumento. Essa constatação se mostra válida, tendo em vista que o art. 136, ora comentado, deixou vaga a expressão "decisão interlocutória" nesse caso, o que poderia levar a um entendimento de dúvida acerca da possibilidade recursal.

Ainda que não houvesse a previsão do art. 1.015, IV, CPC/15, poderse-ia enquadrar o recurso à decisão interlocutória que resolve o IDPJ na hipótese do art. 1.015, II, CPC/15 $5^{90}$, que prevê o cabimento de Agravo de Instrumento em face de decisões interlocutórias de mérito. Isto porque, conforme define o professor HUMBERTO THEODORO JÚNIOR, “seja a

\footnotetext{
${ }^{89}$ Código de Processo Civil de 2015, art. 1.015: “Cabe agravo de instrumento contra as decisões interlocutórias que versarem sobre: (...) IV - incidente de desconsideração da personalidade jurídica;"

${ }^{90}$ Código de Processo Civil de 2015, art. 1.015: "Cabe agravo de instrumento contra as decisões interlocutórias que versarem sobre: (...) II - mérito do processo;"
} 
desconsideração pleiteada na inicial ou em incidente, envolverá sempre questão de mérito, capaz de ampliar o objeto do processo"91, sendo que, em razão disso, há a formação de coisa julgada material após o término de recursos em um IDPJ, o que apenas pode ser mudado em sede de ação rescisória. Assim, no que pese a vagueza do caput do art. 136, mesmo na ausência da previsão específica recursal do IDPJ constante no inciso IV do art. 1.015 do atual diploma processual, ainda seria cabível a interposição de Agravo de Instrumento. De qualquer maneira, em felizardo exemplo de coesão, o CPC/15 expurgou quaisquer dúvidas acerca do recurso cabível.

Nesse ponto, é importante lembrar que, conforme visto linhas acima, o pedido de desconsideração da personalidade jurídica realizado na petição inicial dispensará a instauração do IDPJ. Consequentemente, nesses casos, a questão da desconsideração será decidida por sentença, da qual caberá Apelação. Entretanto, como determina o dispositivo ora analisado, o IDPJ será resolvido por decisão interlocutória, da qual cabe Agravo de Instrumento. Ou seja, haverá situações em que a desconsideração será decida por sentença e, em outras, por decisão interlocutória, o que ensejará interposição de recursos diferentes, que terão consequências para a possibilidade de sustentação oral do advogado nos tribunais, uma vez que, em um recurso (Apelação) isso será admitido, e no outro (Agravo de Instrumento), haverá, a princípio, obstrução a essa faculdade. Esse dilema será mais adiante abordado.

\section{III.2.5 - Art. 137.}

Encerrando as regras gerais para o IDPJ, o art. 137 traz regramento para o processo de execução que se constitui como uma consequência da efetivação do instituto para os direitos do credor:

\footnotetext{
${ }^{91}$ THEODORO JÚNIOR, Humberto. 2016. p. 405.
} 
"Art. 137. Acolhido o pedido de desconsideração, a alienação ou a oneração de bens, havida em fraude de execução, será ineficaz em relação ao requerente."

Assim, consoante já é cediço nas regras que regem a fraude à execução, uma vez esta constatada, seus efeitos ficam inválidos em relação ao exequente lesado pela atitude irresponsável do devedor.

Aqui, está se considerando atos fraudulentos realizados pelo demandado no curso do IDPJ. Desse modo, conforme alerta feito por NELSON NERY JUNIOR ${ }^{92}$, só serão considerados atos em fraude à execução aqueles cometidos quando (i) o demandado já tenha sido citado para responder o IDPJ ou (ii), de qualquer forma, possa-se constatar que o requerido já sabia da existência dessa demanda incidental. Nada obstante, essa última hipótese deve ser aventada apenas com a devida comprovação nos autos do processo, com direito à ampla defesa para o demandado, eis que se configura como uma possibilidade subjetiva que depende, para sua configuração, do que ocorreu no caso concreto.

\section{III.3 - ENALTECIMENTO DO INSTITUTO DO IDPJ: AMPLA COGNIÇÃO QUE PRIMA PELA ATENDIMENTO Às GARANTIAS CONSTITUCIONAIS PROCESSUAIS PARA O DEMANDADO.}

Conforme visto no Capítulo III.2.3, o art. 135 do CPC/15 prevê que o sócio da sociedade cuja personalidade jurídica periga no processo de IDPJ (ou a própria sociedade, em situações de desconsideração inversa ou quando o demandante assim o quiser) deverá ser citado para apresentar resposta em 15 (quinze) dias. Essa modalidade de intimação, somada ao requerimento de provas, decisão interlocutória de mérito, posterior possibilidade recursal e formação de coisa julgada material que só pode ser modificada via ação rescisória são resultado da vital ampla cognição que essa nova Intervenção de Terceiros traz ao ordenamento jurídico processual pátrio. Nesse passo,

\footnotetext{
${ }^{92}$ NERY JUNIOR, Nelson. Código de processo civil comentado. 16. ed. rev., atual. e ampl. - São Paulo: Revista dos Tribunais, 2016. p. 628.
} 
esse somatório de características fomenta a ampla defesa e o contraditório para o demandado, aspectos que, definitivamente, são contemplados com o advento do instituto do IDPJ. ${ }^{93}$

A citação, especificamente, simboliza um marco na consagração da ampla defesa e do contraditório, conforme defende FREDIE DIDIER JR. ${ }^{94}$, afirmando o ilustre doutrinador que a previsão da citação para o demandado encerra quaisquer discussões acerca da necessidade ou não desse polo processual de se defender (ficando claro, portanto, que, a partir de agora, o seu direito de defesa é fundamental), e, de um modo definitivo, relega à História do Direito os antigos debates sobre o tema.

Nessa toada, deve ser prestigiada a lição de DANIEL AMORIM ASSUMPÇÃO NEVES:

\begin{abstract}
"Ao prever que, instaurado o incidente de desconsideração da personalidade jurídica, o sócio ou a pessoa jurídica será citada para manifestar-se e requerer as provas cabíveis no prazo de quinze dias, o art. 135 do Novo CPC consagrou a exigência do contraditório tradicional para a desconsideração da personalidade jurídica, antes de ser proferida a decisão. Atendeu, assim, parcela da doutrina que, mesmo sem previsão expressa, já se posicionava nesse sentido." 95

Assim, confere-se força legal, dentro de uma possibilidade processual, a direitos fundamentais básicos de litigantes. Afinal, os sócios possuem o direito de defender a separação de seus bens em relação a pessoa jurídica da qual fazem parte, em homenagem ao princípio da autonomia patrimonial, que, apenas excepcionalmente, pode ser quebrada. Levantar o véu da sociedade, em casos de obrigatoriedade de prova de abuso de direito ou fraude, sem a audiência daqueles que poderão ser responsabilizados, seria presumir que um ato ilícito fora cometido, o que definitivamente deve ser rechaçado pelo operador do Direito.
\end{abstract}

Ao garantir uma ampla defesa e um contraditório dignos, estar-se-á a garantir uma defesa condizente à natureza da desconsideração da

\footnotetext{
${ }^{93}$ ALMEIDA JUNIOR, Jesualdo Eduardo de. 2016. p. 295.

${ }^{94}$ DIDIER JR., Fredie. 2015. p. 521.

${ }^{95}$ NEVES, Daniel Amorim Assumpção. 2016. p. 311.
} 
personalidade jurídica, que possui o lastro também de sanção, tendo em vista que a aplicação do instituto se revela como uma punição ao sócio que gere de modo fraudulento a sociedade do qual ele faz parte. Nesse sentido, precisas as palavras de LORRUANE MATUSZEWSKI MACHADO e JONATHAN BARROS VITA:

\begin{abstract}
"Um grande avanço trazido pela legislação processual foi a previsão expressa da necessidade de contraditório, conforme prevê a redação do novo artigo 135 (...)

Tal previsão foi um grande avanço na teoria da desconsideração da personalidade jurídica. A previsão do contraditório decorre diretamente do entendimento do afastamento da autonomia patrimonial como sanção. Não é possível sancionar o ente personalizado diretamente, sem manifestação prévia. A constrição patrimonial de uma sociedade empresária pode gerar efeitos nefastos, inviabilizado o próprio exercício da atividade, de forma que a postergação do contraditório descumpre de forma indevida a garantia de um ente de relevada importância para o desenvolvimento social." 96
\end{abstract}

Nesse passo, cumpre ressaltar que os direitos fundamentais ora abordados, quais sejam, a ampla defesa e contraditório, além do devido processo legal, previstos, respectivamente, no art. $5^{\circ}$, incisos $\mathrm{LV}^{97}$ e $\mathrm{LIV}^{98}$, CFRB/88, são partes indissociáveis do princípio da proteção judiciária, consagrada no art. $5^{\circ}, \mathrm{XXXV}^{99}, \mathrm{CFRB} / 88$, completando a gama de garantias constitucionais processuais ${ }^{100}$. Nesse caso, não se poderia, em nome de uma eventual maior celeridade processual ${ }^{101}$, negligenciar essas prerrogativas constitucionais, sob pena de um Direito Processual Civil autoritário e injusto.

Não obstante a razoável duração do processo ser igualmente um direito fundamental, consoante se extrai do texto legal do art. $5^{\circ}$, LXXVIII ${ }^{102}$,

\footnotetext{
96 MACHADO, Lorruane Matuszewski; VITA, Jonathan Barros. Desconsideração da Personalidade Jurídica e as Alterações do Novo Código de Processo Civil: uma análise à luz da função social da empresa. Em: Revista de Processo. ano 42. vol. 266. abr., 2017. p. 167-168.

${ }^{97}$ Constituição da República Federativa do Brasil de 1988, art. $5^{\circ}$ : "LV - aos litigantes, em processo judicial ou administrativo, e aos acusados em geral são assegurados o contraditório e ampla defesa, com os meios e recursos a ela inerentes;"

${ }^{98} \mathrm{O}$ aludido artigo se encontra reproduzido na nota de rodapé $\mathrm{n}^{\circ} 58$.

${ }^{99}$ Constituição da República Federativa do Brasil de 1988, art. 5: "XXXV - a lei não excluirá da apreciação do Poder Judiciário lesão ou ameaça a direito;"

${ }^{100}$ SILVA, José Afonso da. Curso de direito constitucional positivo. 39. ed., rev. e atual. São Paulo: Editora Malheiros, 2016. p. 433-435.

${ }^{101}$ Conforme foi abordado no Capítulo III.1.

102 Constituição da República Federativa do Brasil de 1988, art. 5: "LXXVIII - a todos, no âmbito judicial e administrativo, são assegurados a razoável duração do processo e os meios que garantam a celeridade de sua tramitação."
} 
CFRB/88, não se pode perder de vista que não existe nenhum direito fundamental absoluto. Nesse passo, como não há hierarquia institucional entre os direitos fundamentais previstos na Constituição da República, devese ter em vista que a melhor forma de atender direitos aparentemente conflitantes é fazer uma compatibilização entre eles: restringir ao mínimo e garantir ao máximo os direitos fundamentais.

É o que ensina, brilhantemente, o ministro do STF, LUÍs ROBERTO BARROSO:

\begin{abstract}
"Portanto, na harmonização de sentido entre normas contrapostas, o intérprete deverá promover a concordância prática entre os bens jurídicos tutelados, preservando o máximo possível cada um. Em algumas situações, precisará recorrer a categorias como a teoria dos limites imanentes: os direitos de uns têm de ser compatíveis com os direitos de outros. E em muitas situações, inexoravelmente, terá de fazer ponderações, com concessões recíprocas e escolhas. Adiante, se voltará ao ponto." 103
\end{abstract}

Dessa ideia, pode-se concluir que não se deve atender a um direito fundamental determinado, se isso ferir de morte a outro. In casu, é possível vislumbrar que não se mostra coerente que se sacrifique o devido processo legal, materializado na ampla defesa e no contraditório, em nome da razoável duração do processo. Isto porque, podemos atender uma ampla cognição, com vasta defesa principalmente para o demandado, sem que isso necessariamente implique em uma morosidade excessiva ao processo. Agora, caso se perca de vista a robusta defesa em nome de uma agilidade processual, todo o ideal de justiça que representa o objeto de um processo judicial estará lamentavelmente perdido.

\title{
III.4 - Algumas InCONSISTÊNCIAS DO INSTITUTO DO INCIDENTE DE Desconsideração da Personalidade Jurídica.
}

No que pesem os benefícios trazidos pelo IDPJ - notadamente, conforme visto acima, a garantia dos direitos processuais fundamentais para

103 BARROSO, Luís Roberto. Curso de direito constitucional contemporâneo: os conceitos fundamentais e a construção do novo modelo. 5. ed. - São Paulo: Saraiva, 2015. p. 339. 
os sócios ou a sociedade, nos casos de desconsideração inversa -, o novo instituto carrega consigo alguns problemas relevantes. Essas inconsistências, conforme se verá, estão concentradas em dois aspectos importantes do Direito Processual Civil, quais sejam, (i) a percepção de honorários sucumbenciais pelos patronos dos demandados, nos casos em que suas defesas forem colhidas, e (ii) a sustentação oral em tribunais para esses mesmos advogados, que pode ser prejudicada pela modalidade recursal regente do IDPJ.

\section{III.4.1 - Cabimento de honorários advocatícios nOS casos de INDEFERIMENTO DO IDPJ.}

Os honorários sucumbenciais, sendo estes percebidos, no âmbito de uma demanda judicial, pelos advogados da parte vencedora em um processo, estão disciplinados no art. 85, CPC/15. Nesse dispositivo, logo no caput, é possível vislumbrar a clara determinação de que " [a] sentença condenará o vencido a pagar honorários ao advogado do vencedor" sendo que, em seu $\S$ $1^{\circ 104}$, há a necessária expansão do instituto, propagando seu débito, da parte vencida para a vencedora, para outros casos, como a fase executória e eventuais recursos.

Ocorre que, conforme visto, o art. 136, CPC/15, determina que o IDPJ, quando instaurado, será decidido por decisão interlocutória. Ou seja, não há proferimento de sentença em sede de IDPJ, o que pode configurar um afastamento da aplicação de honorários sucumbenciais, dada a redação do caput do art. 85, CPC/15. Caso o IDPJ seja acolhido, os demandados serão incluídos no polo passivo da demanda principal, que será decidida naturalmente por sentença, possibilitando o arbitramento de possíveis honorários sucumbenciais por ocasião de seu proferimento. Portanto, a

\footnotetext{
104 Código de Processo Civil de 2015, art. 85: "\$ $1^{o}$ São devidos honorários advocatícios na reconvenção, no cumprimento de sentença, provisório ou definitivo, na execução, resistida ou não, e nos recursos interpostos, cumulativamente."
} 
questão problemática advém em situações nas quais há o desprovimento do IDPJ, ocasiões em que não haverá uma sentença que englobe os demandados que não figurem na ação principal e, por consequência, seus respectivos advogados.

Outrossim, os tribunais ${ }^{105}$ têm afastado a possibilidade de se determinar o pagamento de honorários em sede de IDPJ justamente por ausência de previsão legal no art. $85, \S 1^{\circ}, \mathrm{CPC} / 15$, sob o argumento da falta de menção a honorários em sede de incidente processuais pelo referido texto legal.

Entretanto, não se revela difícil a constatação de que aqueles patronos dos demandados, cujas defesas são acolhidas (o que extingue, por consequência, o respectivo IDPJ), atuam apenas no âmbito do referido incidente processual. Logo, acolher a ideia de que os honorários sucumbenciais não são cabíveis em sede do aludido instituto seria privar esses profissionais de receber pelo seu árduo trabalho, relativamente à qualidade do serviço prestado e o tempo despendido para a execução deste. Prova dessa dedicação profissional é o fato de que, se o IDPJ foi desprovido por mérito da defesa, é porque essa resposta foi, de fato, bem elaborada. Nesse passo, não custa lembrar que um dos parâmetros para fixação dos honorários, conforme o art. $85, \S 2^{\circ}$, I e IV, CPC/15 $5^{106}$, é a responsabilidade processual civil do advogado na condução do processo, tanto no mérito do trabalho apresentado quanto no tempo gasto em sua execução.

Nesse sentido, não se pode privar o advogado do recebimento de seus honorários oriundos de processos nos quais se sagre vencedor, uma vez que

\footnotetext{
${ }^{105}$ Como exemplo da utilização dessa linha argumentativa, os seguintes julgados: TJRJ, Agravo de Instrumento $\mathrm{n}^{\circ}$ 0032273-03.2018.8.19.0000, rel. Des. Cherubin Helcias Schwartz Junior, Décima Segunda Câmara Cível, j. 25.10.2018; TJSP, Agravo de Instrumento $\mathrm{n}^{\circ} 2049273$ 50.2019.8.26.0000, rel. Des. Sergio Gomes, $37^{\mathrm{a}}$ Câmara de Direito Privado, j. 15.04.2019; TJRS, Agravo de Instrumento $\mathrm{n}^{\circ}$ 0022967-68.2019.8.21.7000, rel. Des. Pedro Luiz Pozza, Décima Segunda Câmara Cível, j. 28.03.2019.

${ }^{106}$ Código de Processo Civil de 2015, art. 85: "§ $2^{\circ}$ Os honorários serão fixados entre o mínimo de dez e o máximo de vinte por cento sobre o valor da condenação, do proveito econômico obtido ou, não sendo possível mensurá-lo, sobre o valor atualizado da causa, atendidos: I - o grau de zelo do profissional; (...) IV - o trabalho realizado pelo advogado e o tempo exigido para o seu serviço."
} 
essa verbas se constituem como um direito da atividade advocatícia e se notabilizam por sua natureza de prestação alimentar, consoante art. 85, § 14, $\mathrm{CPC} / 15^{107}$. Ou seja, o advogado depende de seu recebimento para sua sobrevivência profissional, tendo em vista que, conforme lecionado por HUMBERTO THEODORO JÚNIOR ${ }^{108}$, o pagamento de honorários advocatícios não tem como finalidade o ressarcimento da parte no processo, mas sim, possui como destinatário diretamente o advogado atuante.

Uma possível saída para esse entrave seria a adoção do princípio da causalidade para o arbitramento de honorários sucumbenciais nesse caso. Segundo essa noção processual, o devedor de honorários sucumbenciais será aquele que deu causa à existência do processo, até mesmo em casos que não tenha sido o vencido na demanda. ${ }^{109}$

A importância desse princípio é destrinchada por ALEXANDRE DE FREITAS CÂMARA, na oportunidade em que este faz a seguinte afirmação:

\begin{abstract}
"A rigor, porém, a regra aplicável é a da causalidade, de que a sucumbência é, tão somente, o retrato daquilo que costumeiramente acontece (id quod plerumque accidit). É que, na verdade, a obrigação de arcar com o custo econômico do processo, pagando as despesas processuais e os honorários advocatícios, deve recair sobre aquele que deu causa ao processo (e que, na maioria das vezes - mas nem sempre - sai vencido). (...)"110
\end{abstract}

Na verdade, em uma situação em que o demandante seja derrotado no IDPJ, não se está diante de um caso de aplicação do princípio da causalidade no sentido de condenar uma parte, mesmo que vencedora, ao pagamento da verba sucumbencial. Nesse caso, poder-se-ia aplicar o princípio da sucumbência em sua acepção clássica, para condenar o vencido a arcar com o ônus sucumbencial. A questão tratada aqui é que, como visto, por ausência de previsão legal, não se tem utilizado o princípio da sucumbência em sede

\footnotetext{
${ }^{107}$ Código de Processo Civil de 2015, art. 85: "§ 14. Os honorários constituem direito do advogado e têm natureza alimentar, com os mesmos privilégios dos créditos oriundos da legislação do trabalho, sendo vedada a compensação em caso de sucumbência parcial."

${ }^{108}$ THEODORO JÚNIOR., Humberto. 2016. p. 306.

${ }^{109}$ NEVES, Daniel Amorim Assumpção. 2016. p. 216.

${ }^{110}$ CÂMARA, Alexandre de Freitas. 2016. p. 68
} 
de IDPJ para os advogados dos demandados cujas defesas são acolhidas, abrindo a oportunidade para a utilização do princípio da causalidade.

Ainda na seara da condenação aos honorários sucumbenciais, é relevante destacar que aquele que dá ensejo à instauração de um IDPJ deve ter a noção de que possui a pretensão primária de incluir mais pessoas no polo passivo de uma demanda já existente. Ou seja, existe a possibilidade que o custo sucumbencial do processo, por culpa exclusiva dele, aumente. Acerca dessa responsabilidade, conforme assinala FlÁvio LUIZ YARSHELL ${ }^{111}$, o demandante da desconsideração deve ter em mente que a inclusão que pretende no polo passivo da demanda possui consequências, uma vez que o inchaço do polo passivo potencializa eventuais custas e honorários de advogado.

Nesse sentido, lembra LUCIANO BENETTI TIMM ${ }^{112}$ que os honorários sucumbenciais, além da função de remunerar os advogados, também possuem o objetivo de demover alguém do ajuizamento de uma ação desnecessária, tendo em vista que essa verba potencializa o custo econômico de uma demanda. Isto visa, segundo o autor, o afastamento de uma possível litigância predatória.

Desse modo, o princípio da causalidade, em sentido estrito de condenar quem deu causa ao nascimento do processo a pagar honorários sucumbenciais ao advogado de seu ex adverso vitorioso, deve ser a solução aplicada à situação ora analisada em sede de IDPJ, com o escopo de trazer justiça ao trabalho dos patronos dos demandados, que cumpriram com seu objetivo de evitar que seus representados fossem incluídos no polo passivo do processo principal.

\footnotetext{
111 YARSHELL, Flávio Luiz. 2016. p. 235.

112 TIMM, Luciano Benetti. Parecer - CFOAB - Honorários de Sucumbência (final). Disponível em < http://s.oab.org.br/arquivos/2018/11/059092dc-2319-455d-bdc8-6c98e7de2a02.pdf>. Acesso em 20 nov. 2018.
} 


\section{III.4.2 - PossibILIDADE DE SUSTENTAÇÃo ORAL NO AGRAVO DE INSTRUMENTO INTERPOSTO EM FACE DE DECISÃO INTERLOCUTÓRIA QUE RESOLVEU O IDPJ.}

Outro tema que gera certa apreensão no instituto do IDPJ é o cabimento de sustentação oral em tribunais em eventual recurso ao decisum que resolve o aludido incidente. Isto porque, conforme visto no Capítulo III.2.4, o IDPJ será resolvido por decisão interlocutória, da qual caberá recurso de Agravo de Instrumento, por força do art. 1.015, IV, CPC/15. Essa modalidade decisória, contudo, não está prevista no rol taxativo ${ }^{113}$ do art. 937, CPC/15 ${ }^{114}$, que lista os recursos nos quais será possível a sustentação oral. A princípio, portanto, esse ato do advogado apenas seria possível, na questão ora delineada, caso o regimento interno do respectivo tribunal assim o permitisse, conforme disposição expressa do art. 937, IX, CPC/15, não sem polêmica. ${ }^{115}$ Consoante detalhamento a seguir, esse problema se revela delicado por duas razões principais.

\section{III.4.2.1 - EM RAZÃO DA COMPLEXIDADE DO INSTITUTO: NECESSIDADE DE ATENDIMENTO A AMPLA DEFESA E CONTRADITÓRIO.}

A primeira delas é que, de acordo com o exposto no Capítulo III.3, o IDPJ inaugurou um novo procedimento para a desconsideração da personalidade jurídica, que possui como base uma larga cognição, com atendimento aos necessários princípios da ampla defesa e do contraditório

\footnotetext{
${ }^{113}$ NERY JUNIOR, Nelson. 2016. p. 1.989.

${ }^{114}$ Código de Processo Civil de 2015, art. 937: "Na sessão de julgamento, depois da exposição da causa pelo relator, o presidente dará a palavra, sucessivamente, ao recorrente, ao recorrido e, nos casos de sua intervenção, ao membro do Ministério Público, pelo prazo improrrogável de 15 (quinze) minutos para cada um, a fim de sustentarem suas razões, nas seguintes hipóteses, nos termos da parte final do caput do art. 1.021 : I - no recurso de apelação; II - no recurso ordinário; III - no recurso especial; IV - no recurso extraordinário; $V$ - nos embargos de divergência; VI - na ação rescisória, no mandado de segurança e na reclamação; VII - (VETADO); VIII - no agravo de instrumento interposto contra decisões interlocutórias que versem sobre tutelas provisórias de urgência ou da evidência; IX - em outras hipóteses previstas em lei ou no regimento interno do tribunal."

${ }^{115}$ Em relação a essa possibilidade, digna de nota a crítica de NELSON NERY JR. (Op. Cit., p. 1991), para quem o regimento interno de Tribunal, mesmo quando amplia as possibilidades de sustentação oral previstas no art. 937, CPC/15, age inconstitucionalmente, tendo em vista que apenas lei federal poderia dispor sobre matéria de Direito Processual Civil, à luz do art. 22, I, CRFB/88.
} 
para os sócios. A conclusão lógica retirada desse fato é de que o IDPJ se revela como um procedimento complexo e desafiador para o advogado. Logo, quando discutido em sede de recurso, aqueles mesmos fatos não se constituem como uma questão trivial, mas sim se configuram como um emaranhado de fatos e de direitos de extrema largueza, sobre os quais se demonstra razoável que o advogado tenha tempo e espaço para expor em uma sessão de julgamento.

Como o IDPJ trouxe maior atendimento aos princípios da ampla defesa e do contraditório, podá-los de qualquer modo seria um exemplo de contrassenso. Porém, é exatamente isto que ocorre na vedação à sustentação oral no Agravo de Instrumento interposto em face de decisão que resolve o IDPJ, tendo em vista a importância que a sustentação oral assume em um processo, conforme destrincha FREDIE DIDIER JR.:

\footnotetext{
"Está claro, portanto, que a sustentação oral é manifestação do contraditório, devendo ser assegurada às partes sua produção na sessão de julgamento nos órgãos colegiados. Aos terceiros intervenientes também se confere esse direito. De igual modo, ao Ministério Público deve ser assegurada a possibilidade de produzir sustentação oral, seja quando ele atua como parte, seja quando atua como fiscal da ordem jurídica.

(...)

A sustentação oral, como também se viu, concretiza os princípios do contraditório e da ampla defesa, sendo permitida para viabilizar o debate no julgamento, com que se confere à parte mais um meio para exercer seu direito de influência, contribuindo com o convencimento dos julgadores. A sustentação oral concretiza, igualmente, o princípio da cooperação, inserindo a parte, por seu advogado, no debate a ser travado pelos membros do órgão julgador."116
}

Assim, não se revela razoável que o advogado de um recorrente no caso ora analisado não possua o direito de realizar sustentação oral em sessão de julgamento de tribunal, em virtude da complexidade que cerca um IDPJ, a qual clama por uma ampla defesa e contraditório robustos.

${ }^{116}$ DIDIER JR., Fredie. 2016. p. 63-64. 


\section{III.4.2.2 - EM RAZÃO dO NECESSÁRIO TRATAMENTO ISONÔMICO COM A DESCONSIDERAÇÃO DA PERSONALIDADE JURÍDICA DECIDIDA POR SENTENÇA.}

Consoante o analisado no Capítulo III.2.2, o art. 134, $§ 2^{\circ}, \mathrm{CPC} / 15$, dispõe que o pedido de desconsideração da personalidade jurídica pode ser realizado diretamente na petição inicial, caso em que estará dispensada a instauração de um IDPJ. Nessas situações, a questão da desconsideração será decidida na própria sentença, em cujo julgamento, pelo disposto no art. 937, I, CPC/15, caberá sustentação oral do advogado.

Ocorre que, essa desconsideração decidida em sentença, do ponto de vista do mérito, não seria muito diferente de um veredicto realizado em sede da decisão interlocutória do art. 136, caput, CPC/15. Nesse passo, importante relembrar que, como já analisado no Capítulo III.2.4, a decisão que versa sobre desconsideração da personalidade jurídica sempre diz respeito ao mérito de um processo, em razão da possibilidade de que as ações do demandante expandam o objeto do processo $^{117}$, não se podendo perder de vista que ela realiza coisa julgada material quando ausentes quaisquer possibilidades recursais.

Esse aspecto está apto a justificar uma possibilidade de sustentação oral para os advogados em sede de Agravos de Instrumento que são fruto de uma decisão de mérito (como se revela a decisão final de um IDPJ), tendo em vista sua pouca diferenciação prática em relação a uma sentença, consoante ensinamento de José MiguEl GARCIA MEDINA:

\footnotetext{
"O CPC/15 admite a realização de sustentação oral em agravo de instrumento que verse sobre tutela provisória (art. 937, VIII; o art. 554 do CPC/1973 não admitia sustentação oral em agravo de instrumento). Deve-se admitir sustentação oral, também, em agravo de instrumento interposto contra decisão interlocutória de mérito (cf. art. 1.015, II, do CPC/2015). No caso, não se admite apelação apenas por não se tratar de decisão final (cf. comentário ao art. 203 do CPC/2015), mas isso não altera a substância da decisão recorrida, que, sendo de mérito, tem aptidão para fazer coisa julgada (cf. art. 502 do CPC/2015), podendo ser, contra ela ajuizada ação rescisória (cf. art. 966 do CPC/2015)." 118
}

\footnotetext{
117 THEODORO JÚNIOR., Humberto. 2016. p. 405.

${ }^{118}$ MEDINA, José Miguel Garcia. 2016. p. 1.341.
} 
Na mesma toada, em comparação ao recurso de Apelação, FREDIE DIDIER JR. aponta que a sustentação oral em decisões de mérito se faz perfeitamente possível:

"Embora não haja previsão expressa da sustentação oral em agravo de instrumento interposto contra decisão de mérito, parece claro que ela sempre é possível em casos em que se examina o mérito. Em muitos casos, a decisão será passível de apelação ou de agravo, a depender de uma previsão legal específica. Enfim, há situações em que é apenas circunstancial a decisão de mérito ser atacada por agravo de instrumento ou por apelação. Seria anti-isonômico admitir, nesses casos, a sustentação oral na apelação, mas não a aceitar no agravo de instrumento."119

Desse modo, visto que tanto a decisão que resolve o IDPJ quanto a desconsideração resolvida em uma sentença dizem respeito ao mérito do processo, sendo inexistente a diferença de conteúdo entre elas no que concerne à desconsideração da personalidade jurídica especificamente, se revela fundamental que haja tratamento isonômico entre as questões, a partir do momento em que ambas guardam a semelhança processual necessária para que tenham o mesmo tratamento.

${ }^{119}$ DIDIER JR., Fredie. 2016. p. 65. 


\section{Conclusão}

O advento do novo Código de Processo Civil, sem dúvidas, trouxe inédita roupagem ao instituto da desconsideração da personalidade jurídica no âmbito do Direito Processual Civil. Nesse passo, a previsão de instauração do Incidente de Desconsideração da Personalidade Jurídica se revela o pilar do cumprimento dos princípios da ampla defesa e do contraditório para sócio cuja inclusão de demanda no processo, em detrimento de entendimentos anteriores que buscavam valorizar a duração razoável do processo. Agora, o sócio que, acusado de abusar da personalidade jurídica da sociedade a qual integra, tem grande possibilidade de se defender para que não tenha seu patrimônio afetado por descumprimento de obrigação da qual a pessoa jurídica era titular, em atenção ao relevantíssimo princípio da autonomia patrimonial entre sociedade e pessoa física. Nesse sentido, os aludidos princípios constitucionais são atendidos pela nova Intervenção de Terceiros a partir do momento em que ela prevê uma ampla cognição para o aludido incidente, com faculdade do oferecimento de resposta, previsão expressa de recurso de Agravo de Instrumento em face de sua decisão e futura formação de coisa julgada material.

Em relação a esses aspectos, fez-se importante destacar a problemática acerca do prazo para responder a demanda para a pessoa jurídica cuja personalidade se busca desconsiderar no processo, uma vez que o art. 135, CPC/15, prevê a citação dos demandados e essa pessoa jurídica já faz parte da demanda principal. Nesse caso, a razoável solução a se buscar seria estabelecer o começo do prazo para resposta a partir da citação do último corréu.

Ademais, no tocante à recorribilidade da decisão interlocutória que julga o IDPJ, concluiu-se que a previsão expressa de cabimento de Agravo de Instrumento, constante do art. 1.015, IV, CPC/15, se revela uma positiva redundância, tendo em vista que, ainda que tal dispositivo não existisse, a 
aludida decisão seria perfeitamente recorrível. Isto porque toda decisão que resolve o IDPJ se configura como de mérito, tendo em vista seu escopo de expandir o objeto do processo. Assim, a recorribilidade estaria garantida pelo art. 1.015, II, CPC/15.

Ainda que tenha se enaltecido o valor do novo incidente para o Direito Processual Civil pátrio, a presente monografia não se furtou a relatar alguns problemas do mencionado instituto, sobretudo a questão dos honorários advocatícios para os patronos dos demandados cujo IDPJ é desprovido, bem como sobre a possibilidade de sustentação oral, em sessão de julgamento, pelos profissionais que atuam na demanda.

Acerca da primeira questão, demonstrou-se que há entendimento no sentido de os honorários advocatícios serem apenas arbitrados por sentença, que o IDPJ não possui, eis que decidido por decisão interlocutória. Para se evitar prejuízos para os patronos dos demandados, nesses casos, deve-se aplicar o princípio da causalidade para a determinação da verba honorária, ainda mais porque esse profissional não se pode ver privado da remuneração por seu trabalho que, em caso de desprovimento do IDPJ, foi de fato bem feito, atendendo aos critérios do art. $85, \S 2^{\circ}$, I e IV, CPC/15.

Sobre a problemática da sustentação oral, que existe em razão de o Agravo de Instrumento se caracterizar como a modalidade recursal de um IDPJ, são dois os argumentos que reforçam sua necessidade no âmbito do referido instituto. Primeiramente, o ato de negar essa faculdade ao advogado seria privá-lo de importante mecanismo de contraditório (eis que o IDPJ é incidente de elevado grau de complexidade), o que, por si só, seria incompatível com o próprio instituto. Em segundo lugar, devido ao fato de existir a previsão de sustentação oral para a Apelação em face de uma sentença que eventualmente resolveria uma desconsideração requerida na petição inicial. Nesse caso, importante recordar que o conteúdo dessa sentença não seria muito diferente de uma decisão de mérito, não fazendo 
sentido, portanto, tratamentos diferentes para questões substancialmente iguais. 


\section{REFERÊnCIAS Bibliográficas}

ALMEIDA JUNIOR, Jesualdo Eduardo de. O Incidente de Desconsideração da Personalidade Jurídica das Pessoas Jurídicas no Novo CPC. Em: Revista dos Tribunais. ano 105. vol. 974. dez, 2016. p. 289-301.

BANDEIRA, Gustavo. Relativização da Pessoa Jurídica. Niterói, RJ: Impetus, 2004. 232p.

BARROSO, Luís Roberto. Curso de direito constitucional contemporâneo: os conceitos fundamentais e a construção do novo modelo. 5. ed. - São Paulo: Saraiva, 2015. 576p.

BRUSCHI, Gilberto Gomes. Aspectos processuais da desconsideração da personalidade jurídica. $2^{\mathrm{a}}$ ed. - São Paulo: Saraiva, 2009.

CABRAL, Antonio do Passo; CRAMER, Ronaldo (Coords.). Comentários ao novo código de processo civil. 2. ed. rev. atual. e ampl. Rio de Janeiro: Forense, 2016. 1.691p.

CÂMARA, Alexandre de Freitas. O novo processo civil brasileiro. 2 ed. São Paulo: Atlas, 2016. 
COELHO, Fabio Ulhoa. Curso de direito comercial, volume 2: direito de empresa. - 15. ed. - São Paulo: Saraiva, 2011.

COSTA NETO, Nicolao Dino de Castro; BELLO FILHO, Ney de Barros; COSTA, Flávio Dino de Castro. Crimes e Infrações Administrativas Ambientais: comentários à Lei n. ${ }^{\circ}$ 9.605/98. $2^{\mathrm{a}}$ edição rev. e atual. Brasília: Brasília Jurídica, 2001. 480p.

DIDIER JR., Fredie. Curso de direito processual: introdução ao direito processual civil, parte geral e processo de conhecimento. v.1. 17. ed. Salvador: JusPodivm, 2015. 786p.

DIDIER JR., Fredie. Curso de direito processual: o processo civil nos tribunais, recursos, ações de competência originária de tribunal e querela nullitatis. v.3. 13. ed. - Salvador: JusPodivm, 2016. 720p.

FILHO, Heleno Ribeiro Nunes. A Desconsideração da Personalidade Jurídica à luz do incidente processual trazido pelo novo Código de Processo Civil brasileiro. Em: Revista de Processo. ano 41. vol. 258. ago., 2017. p. 103-122.

GAMA, Guilherme Calmon Nogueira da. Incidente de Desconsideração da Personalidade Jurídica. Em: Revista de Processo. ano 41. vol. 262. dez, 2016. p. 61-85. 
GIORDANI, José Acir Lessa. Curso Básico de Direito Civil: parte geral. $4^{\mathrm{a}}$ edição, revista e atualizada pelo Novo Código Civil - Rio de Janeiro: Lumen Juris, 2006. 290p.

GRANER, Fabio; OLIVON, Beatriz. Governo inclui jurisprudência do STJ sobre confusão patrimonial em MP. Valor Econômico. São Paulo, p. E1, 17 mai. 2019.

GRINOVER, Ada et al.. Código brasileiro de defesa do consumidor: comentado pelos autores do anteprojeto, vol I. Direito Material (arts. $1 .^{\circ}$ a 80 e 105 a 108). 10 ed. revista, atualizada e reformulada - Rio de Janeiro: Forense, 2011.937p.

GOMES, Orlando, 1909-1988. Introdução do direito civil. Revista, atualizada e aumentada, de acordo com o Código Civil de 2002, por Edvaldo Brito e Reginalda Paranhos de Brito. - Rio de Janeiro: Forense, 2008. 489p.

HARARI, Yuval Noah. Sapiens - Uma breve história da humanidade. Tradução Janaína Marcoantonio - Porto Alegre, RS: L\&PM POCKET, 2018. $592 \mathrm{p}$.

LÔBO, Paulo. Direito Civil : parte geral. 3. ed. - São Paulo: Saraiva, 2012. 366 .

MACHADO, Lorruane Matuszewski; VITA, Jonathan Barros. Desconsideração da Personalidade Jurídica e as Alterações do Novo Código 
de Processo Civil: uma análise à luz da função social da empresa. Em: Revista de Processo. ano 42. vol. 266. abr., 2017. p. 153-173.

MARTINS, Fran. Curso de direito comercial: empresa comercial, empresários individuais, microempresas, sociedades comerciais, fundo de comércio. Ed. rev. e atual. Rio de Janeiro: Forense, 2008.

MEDINA, José Miguel Garcia. Novo código de processo civil comentado : com remissões e notas comparativas ao CPC/1973. 4. ed. rev., atual. e ampl. São Paulo: Revista dos Tribunais, 2016. 1805p.

NEGRÃO, Ricardo. Manual de direito comercial e de empresa, volume 1.9. ed. São Paulo: Saraiva, 2012.

NEVES, Daniel Amorim Assumpção. Manual de Direito Processual Civil. 8. Ed - Salvador: JusPodivm, 2016. 1.760p.

NERY JUNIOR, Nelson. Código de processo civil comentado. 16. ed. rev., atual. e ampl. - São Paulo: Revista dos Tribunais, 2016. 2.976p.

PEREIRA, Caio Mario da Silva. Instituições de direito civil, V. 1, Introdução ao direito civil: teoria geral de direito civil. 26. ed. Rio de Janeiro: Forense, 2013. 
REQUIÃO, Rubens. Curso de direito comercial: volume 1. 33. ed., rev. e atual por Rubens Edmundo Requião. São Paulo: Saraiva, 2014.

RIZZARDO, Arnaldo. Parte Geral do Código Civil: Lei $n^{\circ}$ 10.406, de 10.01.2002. $4^{\mathrm{a}}$ ed. Rio de Janeiro: Forense, 2006.

SILVA, José Afonso da. Curso de direito constitucional positivo. 39. ed., rev. e atual. São Paulo: Editora Malheiros, 2016. 936p.

STOLZE, Pablo. A Medida Provisória da "Liberdade Econômica" e a Desconsideração da Personalidade Jurídica (Art. 50, CC) : Primeiras Impressões. Disponível em http://www.flaviotartuce.adv.br/artigos_convidados>. Acesso em 13 mai. 2019.

TAMER, Maurício Antonio. Pontos sobre a Desconsideração da Personalidade Jurídica no Código de Processo Civil de 2015: Conceitos, Posição do Requerido e outros Aspectos Processuais. Em: Revista Brasileira de Direito Comercial, v. 11, jun./jul. 2016, p. 5-21.

TARTUCE, Flávio. A Medida Provisória 881/2019 e as Alterações do Código Civil - Primeira Parte: Desconsideração da personalidade jurídica $e$ função social do contrato. Disponível em <https://flaviotartuce.jusbrasil.com.br/artigos/703994479/a-medidaprovisoria-881-2019-e-as-alteracoes-do-codigo-civil-primeira-parte- 
desconsideracao-da-personalidade-juridica-e-funcao-social-do-contrato>. Acesso em 13 mai. 2019.

TEPEDINO, Gustavo. Temas de direito civil. $4^{\mathrm{a}}$ edição revista e atualizada. - Rio de Janeiro: Renovar, 2008. 598p.

TEPEDINO, Gustavo; BARBOZA, Heloisa Helena; MORAES, Maria Celina Bodin. Código Civil interpretado: Conforme a Constituição da República. Rio de Janeiro: Renovar, 2004. 790p.

THEODORO JÚNIOR, Humberto. Curso de Direito Processual Civil Teoria geral do direito processual civil, processo de conhecimento e procedimento comum - vol. 1. 57. ed. rev., atual. e ampl. - Rio de Janeiro: Forense, 2016. 1.246p.

TIMM, Luciano Benetti. Parecer - CFOAB - Honorários de Sucumbência (final). Disponível em < http://s.oab.org.br/arquivos/2018/11/059092dc2319-455d-bdc8-6c98e7de2a02.pdf>. Acesso em 20 nov. 2018.

TOMASEVICIUS FILHO, Eduardo. MP da "liberdade econômica": o que fizeram com o Direito Civil?. Disponível em $<$ https://www.conjur.com.br/2019-mai-13/direito-civil-atual-mp-liberdadeeconomica-fizeram-direito-civil>. Acesso em 13 mai. 2019. 